\title{
An Electrochemical Study to Evaluate the Effect of Calcium Nitrite Inhibitor to Mitigate the Corrosion of Reinforcement in Sodium Chloride Contaminated $\mathrm{Ca}(\mathrm{OH})_{2}$ Solution
}

\author{
Hwa-Sung Ryu, ${ }^{1}$ Jitendra Kumar Singh, ${ }^{2}$ Han-Seung Lee, ${ }^{2}$ and Won-Jun Park ${ }^{3}$ \\ ${ }^{1}$ Hanyang Experiment and Consulting, Hanyang University, ERICA, Ansan 15588, Republic of Korea \\ ${ }^{2}$ Department of Architectural Engineering, Hanyang University, ERICA, Ansan 15588, Republic of Korea \\ ${ }^{3}$ Department of Building System Engineering, Kangwon National University, Samcheok 25913, Republic of Korea \\ Correspondence should be addressed to Jitendra Kumar Singh; jk200386@hanyang.ac.kr
}

Received 25 November 2016; Accepted 2 February 2017; Published 23 February 2017

Academic Editor: Patrice Berthod

Copyright (C) 2017 Hwa-Sung Ryu et al. This is an open access article distributed under the Creative Commons Attribution License, which permits unrestricted use, distribution, and reproduction in any medium, provided the original work is properly cited.

\begin{abstract}
The effect of calcium nitrite $\left(\mathrm{Ca}\left(\mathrm{NO}_{2}\right)_{2}\right)$ was assessed by electrochemical means such as open circuit potential (OCP), electrochemical impedance spectroscopy (EIS), and potentiodynamic studies in saturated $\mathrm{Ca}(\mathrm{OH})_{2}$ solution contaminated with 0.99 and $7.91 \mathrm{~g} / \mathrm{L} \mathrm{NaCl}$. The preliminary results of OCP showed that the potential is shifted towards positive (noble) side as content of inhibitor increased. The EIS results indicate that $\mathrm{Ca}\left(\mathrm{NO}_{2}\right)_{2}$ works effectively in reduction and initiation of corrosion of steel rebar in $\mathrm{NaCl}$ contaminated $\mathrm{Ca}(\mathrm{OH})_{2}$ solution. Potentiodynamic studies revealed the pitting tendency of steel rebar exposed in $0.99 \mathrm{~g} / \mathrm{L}$ $\mathrm{NaCl}$ at $\left[\mathrm{Cl}^{-} / \mathrm{NO}_{2}{ }^{-}\right]=1.2$ attributed to low conductivity of passive film which causes interference for $\mathrm{Cl}^{-}$ions attack during anodic polarization. The $85.75 \%$ efficiency is found in $0.99 \mathrm{~g} / \mathrm{L}$ at $\left[\mathrm{Cl}^{-} / \mathrm{NO}_{2}^{-}\right]=1.2$. The $\mathrm{Ca}\left(\mathrm{NO}_{2}\right)_{2}$ inhibitor transformed the unstable iron oxides/hydroxides into stable and protective oxides/hydroxides due to its strong oxidizing nature. Therefore, this inhibitor is sufficiently and significantly reducing the corrosion of steel rebar at even its low concentration with 0.99 and $7.91 \mathrm{~g} / \mathrm{L} \mathrm{NaCl} \mathrm{solution}$.
\end{abstract}

\section{Introduction}

The major issue for construction of big structures is corrosion. The corrosion of embedded steel rebar in concrete occurred due to depassivation of it which later causes expansive corrosion and eventually damages the concrete. The depassivation of steel rebar may occur by different ways such as ingress of chloride ions, contaminated aggregates of concrete, deicing salts, and carbonation which causes reduction in $\mathrm{pH}$ of concrete pore solution through atmospheric $\mathrm{CO}_{2}$ [1-11]. Thus, the durability of concrete is depending on workmanship during casting, water/cement ratio, aggregates, thickness of concrete cover, and many more factors causing the health of concrete. Therefore, it is very important to consider above-mentioned factors during the fabrication and erection of big structures regarding corrosion of embedded steel rebar.

The best method to mitigate the corrosion of steel rebar in concrete is to use inhibitors. Different types of inhibitors are being used nowadays which are basically organic and inorganic chemicals. The activity of inhibitors derived on the basis of their use. Three different types of inhibitors such as anodic, cathodic, and mixed type are popularised to use. The inhibitor should be in little amount compared to cement in concrete. The most important factor for considering the inhibitor must be cost effective and easy to dissolve in concrete as well as in water. A considerable research has been out on use of nitrite based corrosion inhibitor to mitigate or reduce or increase the onset time of steel rebar corrosion in $\mathrm{NaCl}$ contaminated environment [12-20]. $\mathrm{Ca}\left(\mathrm{NO}_{2}\right)_{2}$ inhibitor is being used as an admixture in construction field to mitigate the corrosion of steel rebar in accelerated condition [21]. There are plenty of literature available regarding the positive performance of $\mathrm{Ca}\left(\mathrm{NO}_{2}\right)_{2}$ which mitigate or reduce the onset time of steel rebar corrosion in chloride contaminated concrete environment [22-24].

$\mathrm{Ca}\left(\mathrm{NO}_{2}\right)_{2}$ influences the durability of mortars under contaminated chloride and sulphate environments by reducing 
TABLE 1: Details about the composition of studied solutions.

\begin{tabular}{lcc}
\hline$\left[\mathrm{Cl}^{-} / \mathrm{NO}_{2}{ }^{-}\right]$ & $\begin{array}{c}\text { Concentration of } \\
\mathrm{Ca}\left(\mathrm{NO}_{2}\right)_{2}(\mathrm{~g} / \mathrm{L})\end{array}$ & $\begin{array}{c}\text { Concentration of } \\
\mathrm{NaCl}(\mathrm{g} / \mathrm{L})\end{array}$ \\
\hline \multirow{2}{*}{0} & - & 0.99 \\
0.3 & - & 7.91 \\
& 2.24 & 0.99 \\
0.6 & 17.89 & 7.91 \\
& 4.47 & 0.99 \\
\multirow{2}{*}{1.2} & 35.77 & 7.91 \\
& 8.94 & 0.99 \\
& 71.55 & 7.91 \\
\hline
\end{tabular}

the penetration of sulphate ions [25]. $4 \% \mathrm{Ca}\left(\mathrm{NO}_{2}\right)_{2}$ inhibitor reduces the corrosion of embedded steel bars in concrete and no harmful effect was observed on strength of concrete after longer duration of exposure in $3 \% \mathrm{NaCl}$ solution [26]. $\mathrm{Ca}\left(\mathrm{NO}_{2}\right)_{2}$ is proven to work effectively in chloride contaminated $\mathrm{Ca}(\mathrm{OH})_{2}$, solution and concrete environments [27-29]. There is contrary statement given by different researchers regarding the performance of $\mathrm{Ca}\left(\mathrm{NO}_{2}\right)_{2}$ inhibitor [30] and some researcher mentioned the beneficial effect of $\mathrm{Ca}\left(\mathrm{NO}_{2}\right)_{2}$ which does not affect the properties of concrete owing to compatibility with hydration of cement and concrete $[22,31]$. This inhibitor adsorbs on steel surface and acts as strong oxidizing agent which enhances the transformation of unstable ferrous oxides/hydroxides into stable ferric oxides/hydroxides [32, 33].

$\mathrm{Ca}\left(\mathrm{NO}_{2}\right)_{2}$ is cost effective than other corrosion inhibitors and methods to protect the steel rebar embedded in concrete from corrosion. From the literature research it is found that most of the researchers have carried out the experimental studies on high content of $\mathrm{Ca}\left(\mathrm{NO}_{2}\right)_{2}$ such as more than 2$4 \%$ by weight of cement to mitigate or reduce the initiation of corrosion of steel rebar [34]. Most of the research of $\mathrm{Ca}\left(\mathrm{NO}_{2}\right)_{2}$ had carried out the experiment in service condition as an admixture with cement, sand, aggregates, and so forth but the performance of $\mathrm{Ca}\left(\mathrm{NO}_{2}\right)_{2}$ inhibitor in pore solution at different $\left[\mathrm{Cl}^{-} / \mathrm{NO}_{2}{ }^{-}\right]$molar ratio is scarcely available. Therefore, in this communication, we assessed the performance of $\mathrm{Ca}\left(\mathrm{NO}_{2}\right)_{2}$ inhibitor in 0.99 and $7.91 \mathrm{~g} / \mathrm{L}$ $\mathrm{NaCl}$ with different molar ratio of $\left[\mathrm{Cl}^{-} / \mathrm{NO}_{2}{ }^{-}\right]$ranges from 0.0 to 1.2 in saturated $\mathrm{Ca}(\mathrm{OH})_{2}$ solution through different electrochemical experiments.

\section{Experimental Section}

2.1. Materials. $\mathrm{Ca}\left(\mathrm{NO}_{2}\right)_{2}$ inhibitor was added in saturated $\mathrm{Ca}(\mathrm{OH})_{2}$ solution with different content of $\mathrm{NaCl}$. The $\mathrm{Ca}(\mathrm{OH})_{2}$ simulates the condition of concrete environment. The details of studied solutions are shown in Table 1. In present investigation, two concentrations, that is, 0.99 and $7.91 \mathrm{~g} / \mathrm{L} \mathrm{NaCl}$, were added in without and with different content of $\mathrm{Ca}\left(\mathrm{NO}_{2}\right)_{2}$ inhibitor. Different molar ratios of $\left[\mathrm{Cl}^{-} / \mathrm{NO}_{2}{ }^{-}\right]=0$ (without inhibitor), $0.3,0.6$, and 1.2 were taken to study the effect of $\mathrm{Ca}\left(\mathrm{NO}_{2}\right)_{2}$ inhibitor with 0.99 and $7.91 \mathrm{~g} / \mathrm{L} \mathrm{NaCl}$.
Detail of the studied steel rebar was mentioned in our recently published paper $[12,35]$. The black milled scale of $16 \mathrm{~mm}$ steel rebar was descaled by using $10 \mathrm{v} / \mathrm{v} \%$ of $\mathrm{HCl}$, ringed with distilled water and dried. After descaling of milled scale from steel rebar surface, it was cut and mounted in acid/alkali resistance thermosetting resin. The mounted steel rebar was abraded with emery paper started from 180 to $1200 \mu \mathrm{m}$. Thereafter, cloth polished of steel rebar was carried out and degreased with acetone prior to start the electrochemical experiments. The chemistry of studied steel rebar is shown in Table 2.

2.2. Electrochemical Studies. Prior to start the experiments, the steel rebar was exposed in inhibitor and without inhibitor containing saturated $\mathrm{Ca}(\mathrm{OH})_{2}$ solutions to stabilize the potential with potentiostat. Electrochemical studies were performed by three electrode systems where steel rebar works as working electrode (WE), platinum wire as a counter electrode (CE), and silver-silver chloride as a reference electrode (RE). The schematic diagram of the electrochemical cell used in this study is shown in Figure $1[36,37]$. The WE and RE had been fixed in such a manner that both are close to each other, since there will be less solution resistance caused. The area of working electrode was $0.78 \mathrm{~cm}^{2}$ and it was fixed for every sample.

The electrochemical impedance spectroscopy (EIS) studies were carried out at open circuit potential (OCP) by changing the frequency of $10 \mathrm{mV}$ sinusoidal voltage from $100 \mathrm{kHz}$ to $0.1 \mathrm{~Hz}$. DC polarization studies were performed at $1 \mathrm{mV} / \mathrm{s}$ scan rate from $-0.3 \mathrm{~V}$ to $+0.3 \mathrm{~V}$ versus $\mathrm{Ag} / \mathrm{AgCl}$. The potentiostat was VersaSTAT (Princeton Applied Research, Oak Ridge, TN, USA) and data analysis was carried out by Metrohm Autolab Nova 1.10 software by fitting the experimental data in constant phase element (CPE) model.

\section{Results}

3.1. OCP Measurements. The OCP was measured after keeping of steel rebar in solution for $30 \mathrm{~min}$ to stabilize the potential. The OCP plots are shown in Figure 2. This plot depicted that as the inhibitor concentration, that is, $\left[\mathrm{Cl}^{-} / \mathrm{NO}_{2}{ }^{-}\right]$, is increased the potential shifted towards nobler (positive) side compared to that without containing inhibitor; that is, $\left[\mathrm{Cl}^{-} / \mathrm{NO}_{2}^{-}\right]=0.0$. This result indicates that $\mathrm{Ca}\left(\mathrm{NO}_{2}\right)_{2}$ diminishes the penetration of chloride ions. The effect of inhibitor can be seen from OCP plots (Figure 2) that inhibitor reduces the aggressiveness of $\mathrm{Cl}^{-}$ion to break the passive film which later initiate to cause localized corrosion. The OCP of without inhibitor, that is, $\left[\mathrm{Cl}^{-} / \mathrm{NO}_{2}{ }^{-}\right]=0.0$, containing solution shows -333 and $-366 \mathrm{mV}$ for 0.99 and $7.91 \mathrm{~g} / \mathrm{L}$ $\mathrm{NaCl}$, respectively. As the inhibitor was added in $0.99 \mathrm{~g} / \mathrm{L}$ $\mathrm{NaCl}$ solution, the OCP shifted towards positive side from $-300,-279$, and $-254 \mathrm{mV}$ at $\left[\mathrm{Cl}^{-} / \mathrm{NO}_{2}{ }^{-}\right]=0.3,0.6$, and 1.2 , respectively, compared to without inhibitor solution. This result implies that $\left[\mathrm{Cl}^{-} / \mathrm{NO}_{2}{ }^{-}\right]=1.2$ is an effective amount in $0.99 \mathrm{~g} / \mathrm{L} \mathrm{NaCl}$ solution to stifle the reaction on steel/solution interface. It has been determined by other researchers that $\mathrm{Ca}\left(\mathrm{NO}_{2}\right)_{2}$ is an anodic inhibitor owing to shifting of OCP towards nobler side [21,38-40]. The $\mathrm{Ca}\left(\mathrm{NO}_{2}\right)_{2}$ may be able 
TABLE 2: Chemistry of steel rebar (wt.\%).

\begin{tabular}{lcccccccccc}
\hline $\mathrm{C}$ & $\mathrm{Si}$ & $\mathrm{Mn}$ & $\mathrm{P}$ & $\mathrm{S}$ & $\mathrm{Ni}$ & $\mathrm{Cr}$ & $\mathrm{Mo}$ & $\mathrm{Cu}$ & $\mathrm{Sn}$ & $\mathrm{Fe}$ \\
\hline 0.240 & 0.260 & 0.950 & 0.016 & 0.008 & 0.030 & 0.040 & 0.010 & 0.020 & 0.001 & Balance \\
\hline
\end{tabular}

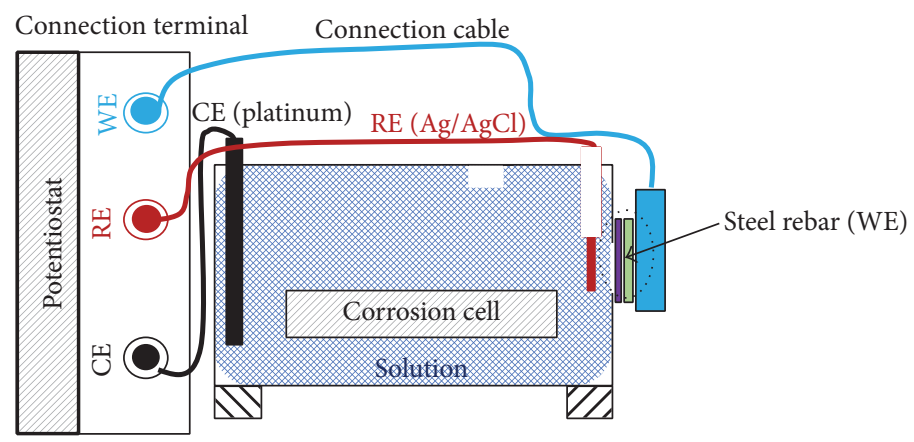

CE: Counter electrode

RE: Reference electrode

WE: Working electrode

FIGURE 1: Schematic diagram of electrochemical cell [36, 37].

to transform the unstable iron oxides film into stable and protective oxides compared to naturally occurring oxides. As the $\mathrm{NaCl}$ content is increased the OCP shifted towards active side attributed to the fact that the preliminary formed passive/oxides film was being destabilized [41]. Saraswathy and Song studied the effect of different inhibitor in durability of concrete and measured the OCP [42]. They found that as the concentration of inhibitors had increased the compressive strength and the threshold potential to break the passive film is increased and it is $-275 \mathrm{mV}$ versus saturated calomel electrode (SCE) in 3\% $\mathrm{NaCl}$ with inhibitor. Above this OCP, the steel is susceptible and led to corrosion as time is increased. In the present investigation, the steel shows the OCP around $-275 \mathrm{mV}$ and above in $0.99 \mathrm{~g} / \mathrm{L} \mathrm{NaCl}$ at $\left[\mathrm{Cl}^{-} / \mathrm{NO}_{2}{ }^{-}\right]=1.2$. This result indicates that this ratio of $\left[\mathrm{Cl}^{-} / \mathrm{NO}_{2}{ }^{-}\right]$is sufficient to resist breaking the passive film in $0.99 \mathrm{~g} / \mathrm{L} \mathrm{NaCl}$ and whenever the content of $\mathrm{NaCl}$ is increased, the steel is becoming susceptible to corrosion and not able to diminish the reaction on steel/solution interface.

3.2. EIS Studies. The EIS studies of steel rebar were carried out at OCP after $30 \mathrm{~min}$ of exposure in different abovementioned solutions (Table 1). The Nyquist plots of without inhibitor containing solution are shown in Figure 3(a). From this figure it can be seen that as the content of $\mathrm{Cl}^{-}$ion is increased the dimension of semicircle loop decreased which attributed that steel rebar is susceptible to corrosion [41]. The decrease in dimension of semicircle loops in Nyquist plots suggests the deterioration of steel in chloride contaminated $\mathrm{Ca}(\mathrm{OH})_{2}$ solution. The preliminary formed oxides/passive film might be perturbed and initiate the deterioration of steel rebar in $7.91 \mathrm{~g} / \mathrm{L} \mathrm{NaCl}$ containing $\mathrm{Ca}(\mathrm{OH})_{2}$ solution due to competition of $\mathrm{OH}^{-}$and $\mathrm{Cl}^{-}$ion in solution. High content of $\mathrm{Cl}^{-}$ions may be dominated over $\mathrm{OH}^{-}$ions and induce the localized corrosion at steel rebar/solution interface [43].

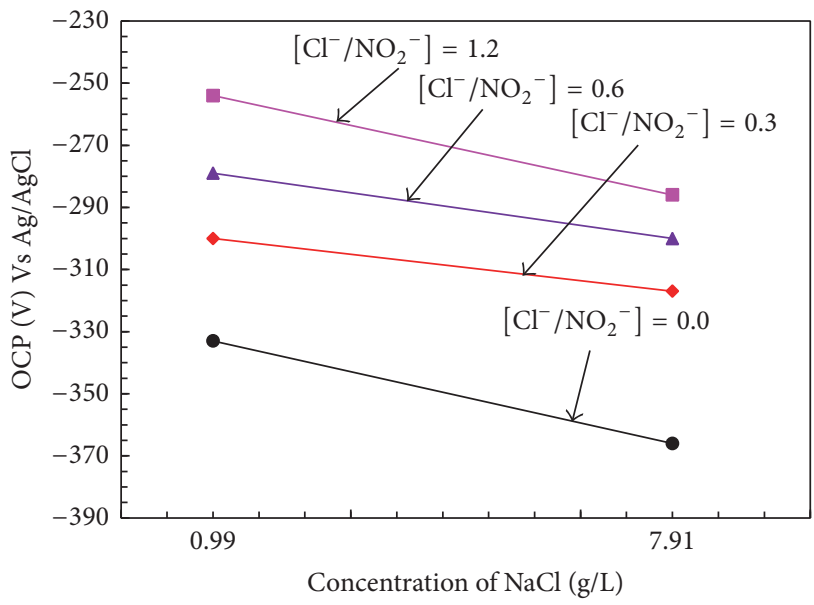

FIGURE 2: OCP plots of steel rebar exposed in saturated $\mathrm{Ca}(\mathrm{OH})_{2}$ solution with different concentration of $\mathrm{NaCl}$ at different molar ratio of $\left[\mathrm{Cl}^{-} / \mathrm{NO}_{2}^{-}\right]$.

The affinity of $\mathrm{Cl}^{-}$ion with steel surface is more than $\mathrm{OH}^{-}$ ion which inhibited the formation of passive film on steel rebar surface in $\mathrm{NaCl}$ containing saturated $\mathrm{Ca}(\mathrm{OH})_{2}$ solution [44]. The bigger size of $-Z_{\text {image. }}^{\prime \prime}$ at $y$-axes of Nyquist plots in $0.99 \mathrm{~g} / \mathrm{L} \mathrm{NaCl}$ indicates capacitive properties of oxides film while $7.91 \mathrm{~g} / \mathrm{L} \mathrm{NaCl}$ exhibit smaller dimension due to corrosion process. At the same time $Z_{\text {real }}^{\prime}$ at $x$-axes exhibits almost identical values for both concentrations of $\mathrm{NaCl}$. This result attributed that $0.99 \mathrm{~g} / \mathrm{L} \mathrm{NaCl}$ is not able to initiate the corrosion of steel rebar in saturated $\mathrm{ca}(\mathrm{OH})_{2}$ solution.

The comparative studies of impedance in $\mathrm{NaCl}$ containing solution were performed to measure the polarization resistance of steel rebar. The log-modulus impedance Bode plots of steel rebar exposed in $\mathrm{NaCl}$ contaminated $\mathrm{Ca}(\mathrm{OH})_{2}$ 


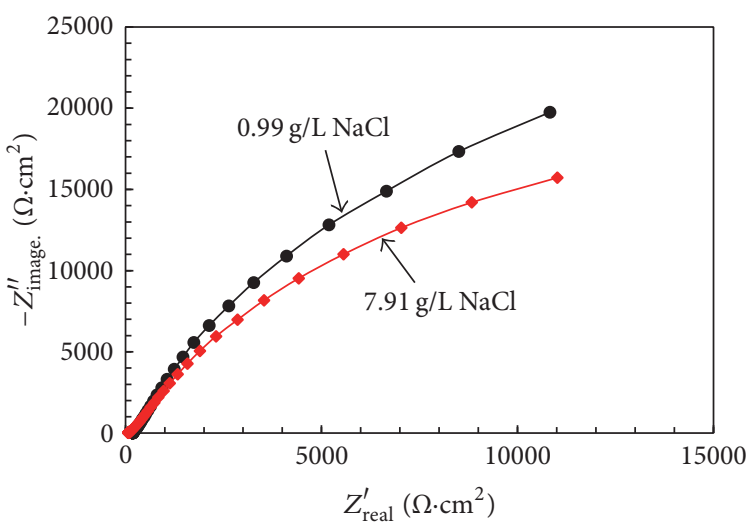

(a) Nyquist plots of steel rebar (without inhibitor)

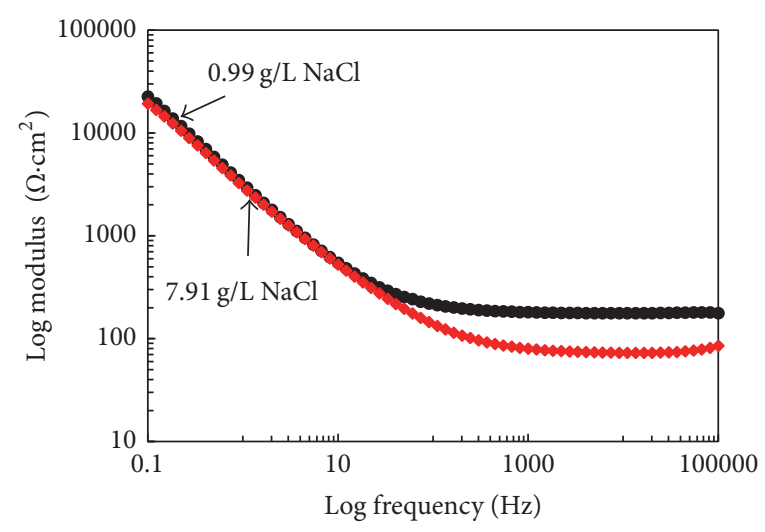

(b) Impedance-frequency Bode plots (without inhibitor)

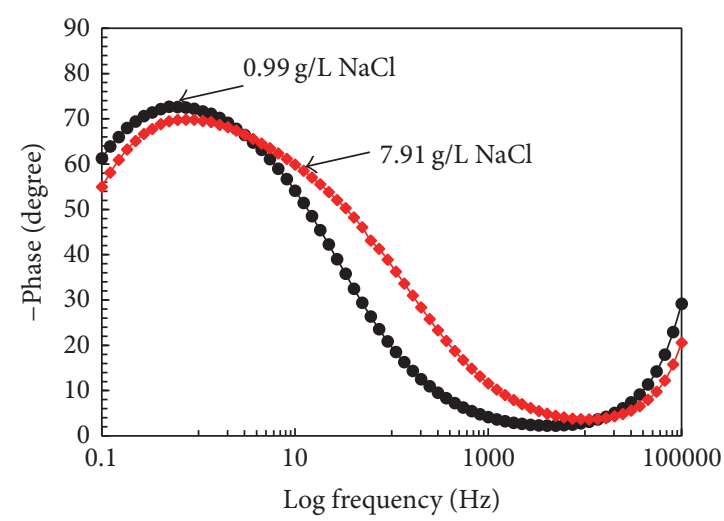

(c) Phase-frequency Bode plots (without inhibitor)

FIGURE 3: Electrochemical plots of steel rebar exposed in saturated $\mathrm{Ca}(\mathrm{OH})_{2}$ solution with different concentrations of $\mathrm{NaCl}$.

solution are shown in Figure 3(b). The impedance values of steel rebar were measured at lowest studied frequency, that is, $0.1 \mathrm{~Hz} .0 .99 \mathrm{~g} / \mathrm{L} \mathrm{NaCl}$ containing solution exhibits higher values than $7.91 \mathrm{~g} / \mathrm{L} \mathrm{NaCl}$ at this frequency. This result indicates that $7.91 \mathrm{~g} / \mathrm{L} \mathrm{NaCl}$ is more than sufficient to influence the deterioration of steel rebar than $0.99 \mathrm{~g} / \mathrm{L}$ $\mathrm{NaCl}$ solution. This result attributed that $7.91 \mathrm{~g} / \mathrm{L} \mathrm{NaCl}$ was barred to form the passive/oxide films on steel rebar/solution interface and influences the steel rebar to localized corrosion. One another interesting observation can be seen from Figure 3(b) that as the content of $\mathrm{NaCl}$ is increased the impedance at higher frequency is decreased and this result is due to the conductivity of studied solution [45]. $7.91 \mathrm{~g} / \mathrm{L}$ $\mathrm{NaCl}$ containing solution shows lesser impedance at higher frequency than $0.99 \mathrm{~g} / \mathrm{L} \mathrm{NaCl}$. It is general hypothesis that when the content of solute/ions is increased the conductivity of solution also increased.

The phase-frequency Bode plots are shown in Figure 3(c). The $0.99 \mathrm{~g} / \mathrm{L} \mathrm{NaCl}$ shifted the phase angle maxima at $-73^{\circ}$ towards lower frequency; that is, $0.5 \mathrm{~Hz}$ indicates the capacitive properties of passive/oxides films on steel rebar/solution interface while $7.91 \mathrm{~g} / \mathrm{L}$ exhibits $-69^{\circ}$ on $1.0 \mathrm{~Hz}$. This result indicates that $0.99 \mathrm{~g} / \mathrm{L} \mathrm{NaCl}$ is not deterring the formation of capacitive passive film while $7.91 \mathrm{~g} / \mathrm{L} \mathrm{NaCl}$ is attributed to deterioration of steel rebar. Another shifting of maxima towards higher frequency is attributed to corrosion characteristics of steel rebar. The shifting of maxima is approximately from $35 \mathrm{kHz}$ to $3.5 \mathrm{kHz}$ for $7.91 \mathrm{~g} / \mathrm{L} \mathrm{NaCl}$ and from $35 \mathrm{kHz}$ to $0.6 \mathrm{kHz}$ for $0.99 \mathrm{~g} / \mathrm{L} \mathrm{NaCl}$. This finding is attributed to more deterioration of steel rebar in $7.91 \mathrm{~g} / \mathrm{L} \mathrm{NaCl}$ containing solution [46].

As the inhibitor was added in solution with $\mathrm{NaCl}$, the dimensions of semicircle loop of Nyquist plots are increased and this result indicates the positive effects of inhibitor. Bigger dimension of semicircle loops of Nyquist plots is attributed to resistance of corrosion. The bigger size in Nyquist plot covers the active surface area by forming protective oxide films which reduces the anodic surface area of steel. This phenomenon can be correlated with $0.99 \mathrm{~g} / \mathrm{L} \mathrm{NaCl}$ that the dimension of semicircle loops is greater than $7.91 \mathrm{~g} / \mathrm{L} \mathrm{NaCl}$ at $\left[\mathrm{Cl}^{-} / \mathrm{NO}_{2}{ }^{-}\right]=0.3$. The $0.99 \mathrm{~g} / \mathrm{L} \mathrm{NaCl}$ solution with $\mathrm{Ca}\left(\mathrm{NO}_{2}\right)_{2}$ inhibitor forms bigger semicircle loop at $Z_{\text {real }}^{\prime}$ and $-Z_{\text {image. }}^{\prime \prime}$ which is attributed to formation of protective oxides film. It means that the $\mathrm{Ca}\left(\mathrm{NO}_{2}\right)_{2}$ is able to reduce the anodic surface area of steel by formation of more stable, adherent, and protective oxide films.

The impedance values of inhibitor containing solution are gradually increased compared to without inhibitor containing solution with $\mathrm{NaCl}$ (Figure 4(b)). The impedance value of $0.99 \mathrm{~g} / \mathrm{L} \mathrm{NaCl}$ solution is greater than $7.91 \mathrm{~g} / \mathrm{L}$ $\mathrm{NaCl}$ containing $\mathrm{Ca}(\mathrm{OH})_{2}$ solution at $\left[\mathrm{Cl}^{-} / \mathrm{NO}_{2}{ }^{-}\right]=0.3$. The enhancement in impedance of inhibitor containing 


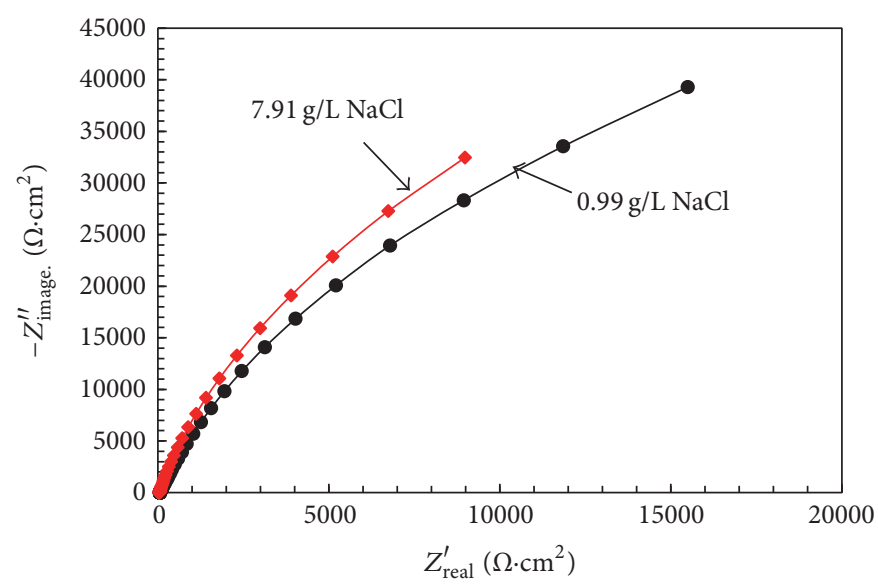

(a) Nyquist plots of steel rebar at $\left[\mathrm{Cl}^{-} / \mathrm{NO}_{2}{ }^{-}\right]=0.3$

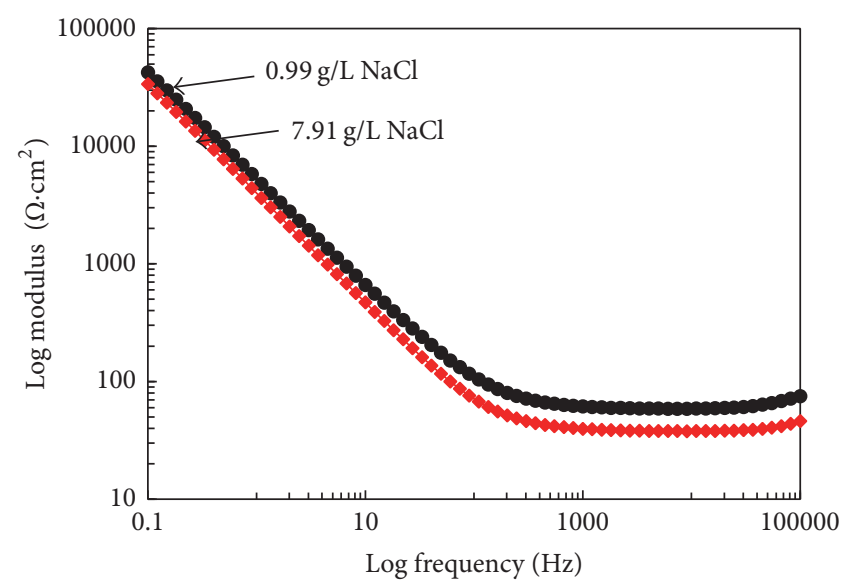

(b) Impedance-frequency Bode plots of steel rebar at $\left[\mathrm{Cl}^{-} / \mathrm{NO}_{2}{ }^{-}\right]=0.3$

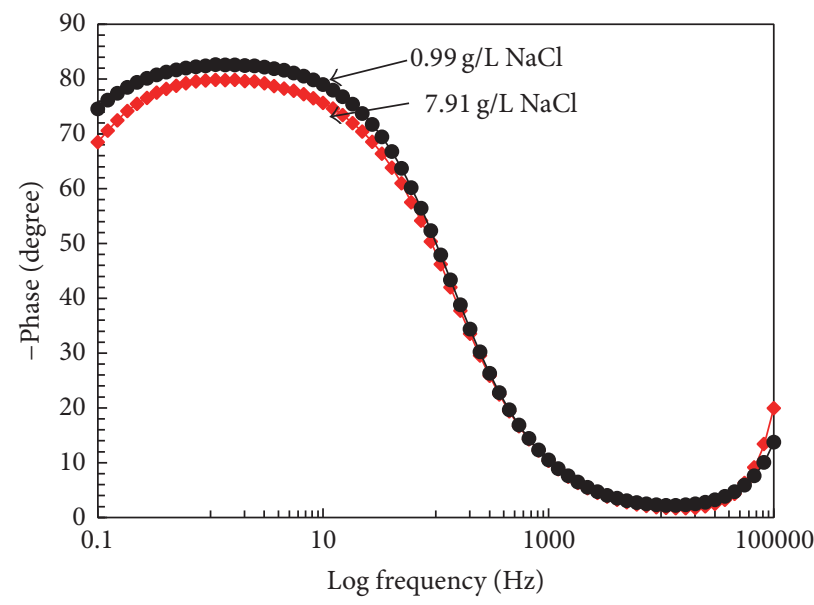

(c) Phase-frequency Bode plots of steel rebar at $\left[\mathrm{Cl}^{-} / \mathrm{NO}_{2}{ }^{-}\right]=0.3$

Figure 4: Electrochemical plots of steel rebar exposed in saturated $\mathrm{Ca}(\mathrm{OH})_{2}$ solution with different concentrations of $\mathrm{NaCl}$ at $\left[\mathrm{Cl}^{-} / \mathrm{NO}_{2}{ }^{-}\right]=$ 0.3 .

solution is attributed to adsorption of it on steel surface and forming thin protective layer which diminishes the attack of chloride ions compared to without inhibitor containing solution (Figure 3(b)). The gradual increment in its value of impedance is attributed to transformation of unstable iron oxides/hydroxides into stable iron oxides/hydroxides. This value is not so much which sustains the protection at longer duration of exposure. Therefore, the higher amount of inhibitor is needed and this will be discussed in subsequent paragraphs.

The significant role of inhibitor can be derived from phase-frequency Bode plots where shifting in maxima towards higher angle is observed (Figure 4(c)). The capacitive properties of passive film exhibit that the maxima in 0.99 and $7.91 \mathrm{~g} / \mathrm{L} \mathrm{NaCl}$ containing solution shifted at $-82^{\circ}$ and $-79^{\circ}$, respectively, at lower studied frequency ranges. Such shifting is found for both concentrations of $\mathrm{NaCl}$ at high ranges from $10 \mathrm{~Hz}$ to $0.3 \mathrm{~Hz}$ at $\left[\mathrm{Cl}^{-} / \mathrm{NO}_{2}{ }^{-}\right]=0.3$. This observation may be due to the adsorption of inhibitor which reduces the anodic surface area of steel but not uniformly. Therefore, there is some chance to attack $\mathrm{Cl}^{-}$ion on passive film which later may cause defect and initiate deterioration of steel at longer duration of exposure.

As the concentration of inhibitor is increased the significant difference is observed in dimensions and orientation of Nyquist plots. $7.91 \mathrm{~g} / \mathrm{L} \mathrm{NaCl}$ containing solution Nyquist plot is suppressed due to larger size of $0.99 \mathrm{~g} / \mathrm{L} \mathrm{NaCl}$ containing solution at $\left[\mathrm{Cl}^{-} / \mathrm{NO}_{2}{ }^{-}\right]=0.6$ (Figure $5(\mathrm{a})$ ). Gradual increment in their value of $Z_{\text {real }}^{\prime}$ in Nyquist plot at $x$-axes of $\mathrm{NaCl}$ containing solution at $\left[\mathrm{Cl}^{-} / \mathrm{NO}_{2}{ }^{-}\right]=0.6$ indicates that the film being formed on steel/solution interface is resistant and gradually decreases the anodic area of steel rebar to reduce the attack of $\mathrm{Cl}^{-}$ion. This increment may be attributed to transformation of unstable iron oxides/hydroxides into stable oxides/hydroxides of iron.

The impedance plots revealed the resistive property of $\mathrm{Ca}\left(\mathrm{NO}_{2}\right)_{2}$ inhibitor on formation of passive film. The impedance values are gradually increased compared to prior studies content of inhibitor and without inhibitor solution (Figure 5(b)). $0.99 \mathrm{~g} / \mathrm{L} \mathrm{NaCl}$ containing inhibitor solution impedance value at lowest studied frequency, that is, $0.1 \mathrm{~Hz}$, is greater than $7.91 \mathrm{~g} / \mathrm{L} \mathrm{NaCl}$ at $\left[\mathrm{Cl}^{-} / \mathrm{NO}_{2}{ }^{-}\right]=0.6$. This 


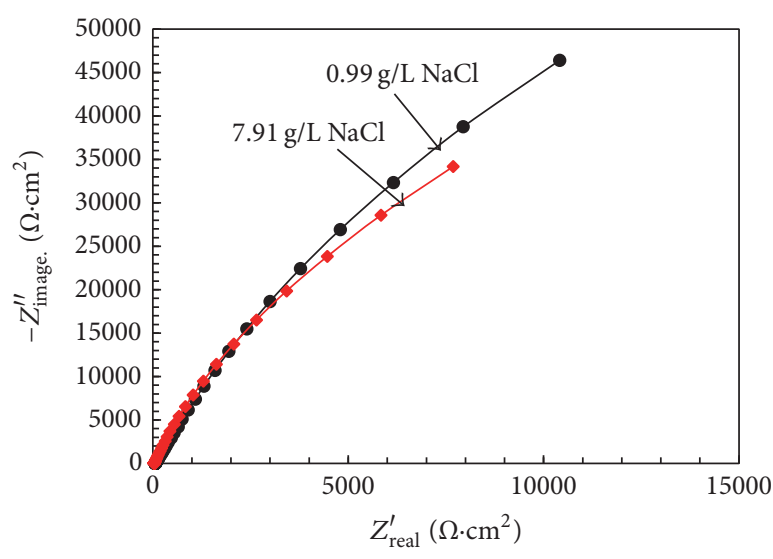

(a) Nyquist plots of steel rebar at $\left[\mathrm{Cl}^{-} / \mathrm{NO}_{2}^{-}\right]=0.6$

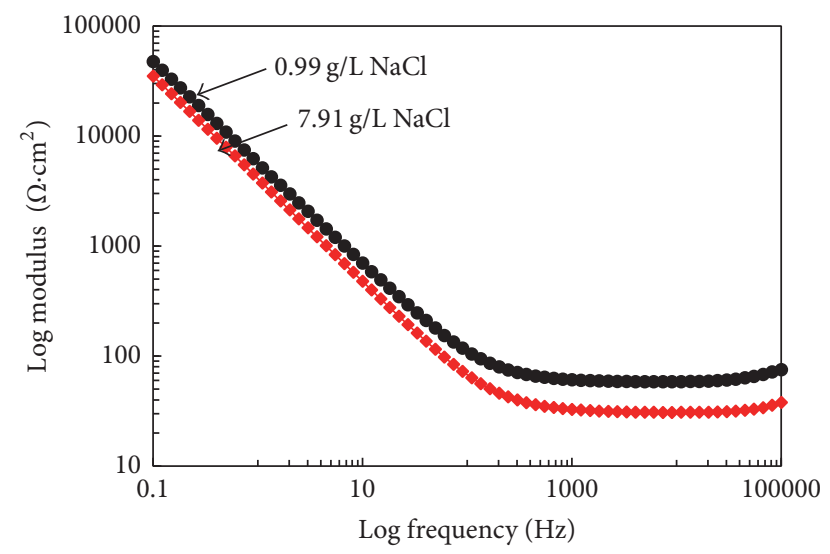

(b) Impedance-frequency Bode plots of steel rebar at $\left[\mathrm{Cl}^{-} / \mathrm{NO}_{2}{ }^{-}\right]=0.6$

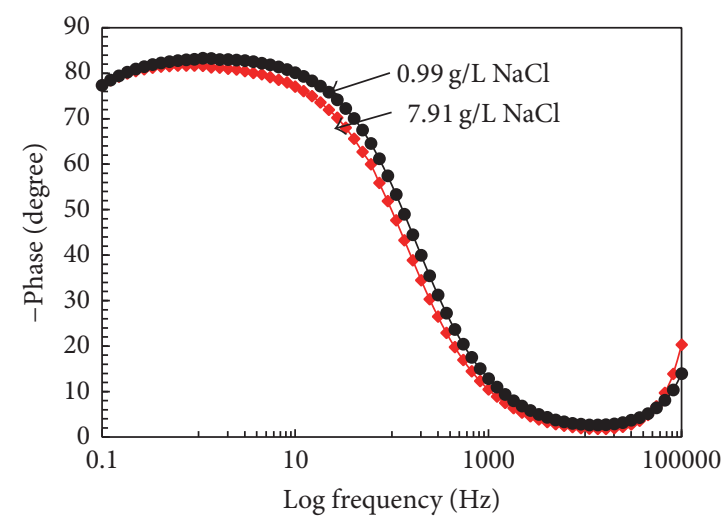

(c) Phase-frequency Bode plots of steel rebar at $\left[\mathrm{Cl}^{-} / \mathrm{NO}_{2}^{-}\right]=$ 0.6

FIGURE 5: Electrochemical plots of steel rebar exposed in saturated $\mathrm{Ca}(\mathrm{OH})_{2}$ solution with different concentrations of $\mathrm{NaCl}$ at $\left[\mathrm{Cl}^{-} / \mathrm{NO}_{2}{ }^{-}\right]=$ 0.6 .

result indicates that higher concentration of inhibitor in low amount of $\mathrm{NaCl}$ is exhibiting positive response in formation of protective passive film.

The phase-frequency Bode plots at $\left[\mathrm{Cl}^{-} / \mathrm{NO}_{2}{ }^{-}\right]=0.6$ in 0.99 and $7.91 \mathrm{~g} / \mathrm{L} \mathrm{NaCl}$ solution are shown in Figure 5(c). The maxima of phase angle of both concentrations of $\mathrm{NaCl}$ are exhibited around $-83^{\circ}$ which is identical as $\left[\mathrm{Cl}^{-} / \mathrm{NO}_{2}{ }^{-}\right]$ $=0.3$. This result attributed that the capacitive property of passive is not altering with amount of inhibitor. This means that the uniform and homogenised passive film was formed on steel rebar surface when the little amount of inhibitor was added in solution. The little amount of $\mathrm{Ca}\left(\mathrm{NO}_{2}\right)_{2}$ is sufficient to transform unstable oxides/hydroxides into stable and protective oxide/hydroxide films. However, to increase the efficiency and strengthen the passive film, higher amount of $\mathrm{Ca}\left(\mathrm{NO}_{2}\right)_{2}$ inhibitor is to be required. Therefore, we have increased the amount of inhibitor at the same content of $\mathrm{NaCl}$.

From the above result, it is confirmed that to increase the efficiency and strengthen the properties of passive film, it is necessary to increase the amount of $\mathrm{Ca}\left(\mathrm{NO}_{2}\right)_{2}$ inhibitor than priorly studied amount. The $-Z_{\text {image. }}^{\prime \prime}$ values of 0.99 and $7.91 \mathrm{~g} / \mathrm{L} \mathrm{NaCl}$ containing solution at $\left[\mathrm{Cl}^{-} / \mathrm{NO}_{2}{ }^{-}\right]=1.2$ are gradually increased as concentration of inhibitor increased
(Figure 6(a)) compared to without inhibitor containing solution attributed to reduction in capacitive property of passive film. On the other hand, in these concentrations of $\mathrm{NaCl}$, the $Z_{\text {real }}^{\prime}$ is increased as concentration of inhibitor increased indicating the more resistance of passive film being formed on steel/solution interface. This observation indicates that the passive film is exhibiting less capacitive properties but more resistance to corrosion. The oxide/passive film is more protective, less porous which does not allow ingress of the $\mathrm{Cl}^{-}$ion towards steel surface. This film works as barrier for aggressive ions. This is evident from Nyquist plots at $\left[\mathrm{Cl}^{-} / \mathrm{NO}_{2}{ }^{-}\right]=1.2$ in 0.99 and $7.91 \mathrm{~g} / \mathrm{L} \mathrm{NaCl}$ containing solution (Figure 6(a)). The dimension and size of Nyquist plots of $0.99 \mathrm{~g} / \mathrm{L} \mathrm{NaCl}$ are greater than $7.91 \mathrm{~g} / \mathrm{L} \mathrm{NaCl}$ at $\left[\mathrm{Cl}^{-} / \mathrm{NO}_{2}{ }^{-}\right]=1.2$. The highest increase in dimension of Nyquist plot for $0.99 \mathrm{~g} / \mathrm{L} \mathrm{NaCl}$ compared to other studied amounts of inhibitor and $\mathrm{NaCl}$ is found. This result indicates that the passive film and transformed oxides/hydroxides are very protective, adherent, and stable with even $\mathrm{NaCl}$ present in solution.

To correlate the Nyquist plots, impedance result is shown in Figure 6(b). $0.99 \mathrm{~g} / \mathrm{L} \mathrm{NaCl}$ containing solution shows the highest impedance value than $7.91 \mathrm{~g} / \mathrm{L} \mathrm{NaCl}$ at $\left[\mathrm{Cl}^{-} / \mathrm{NO}_{2}{ }^{-}\right]=$ 1.2. This value is greater than priorly studied concentrations 


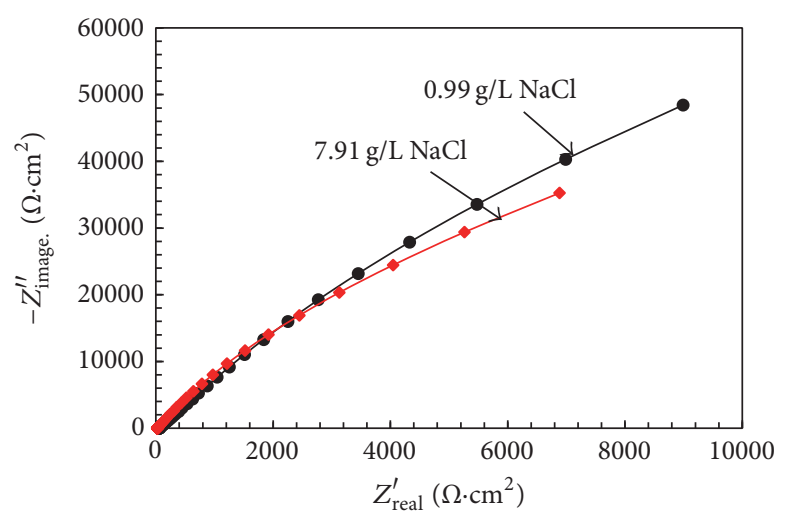

(a) Nyquist plots of steel rebar at $\left[\mathrm{Cl}^{-} / \mathrm{NO}_{2}^{-}\right]=1.2$

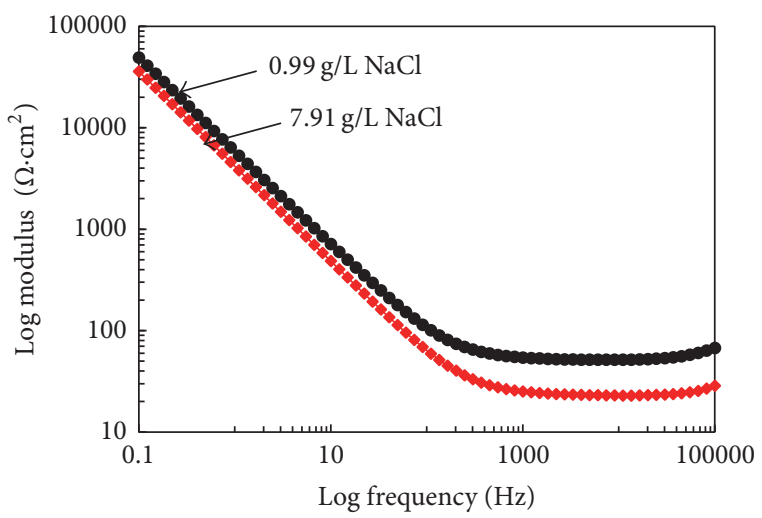

(b) Impedance-frequency Bode plots of steel rebar at $\left[\mathrm{Cl}^{-} / \mathrm{NO}_{2}^{-}\right]=$ 1.2

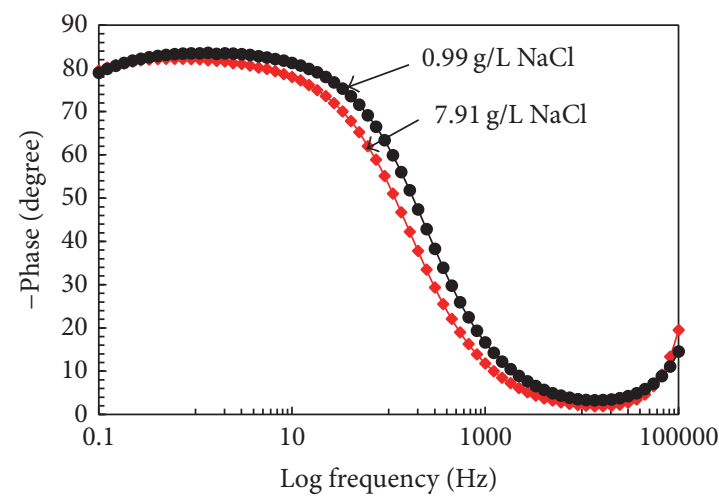

(c) Phase-frequency Bode plots of steel rebar at $\left[\mathrm{Cl}^{-} / \mathrm{NO}_{2}{ }^{-}\right]=$

FIGURE 6: Electrochemical plots of steel rebar exposed in saturated $\mathrm{Ca}(\mathrm{OH})_{2}$ solution with different concentrations of $\mathrm{NaCl}$ at $\left[\mathrm{Cl}^{-} / \mathrm{NO}_{2}{ }^{-}\right]=$ 1.2 .

of inhibitor in 0.99 and $7.91 \mathrm{~g} / \mathrm{L} \mathrm{NaCl}$. At this concentration of $\mathrm{Ca}\left(\mathrm{NO}_{2}\right)_{2}$ inhibitor, passive film is homogenous and uniformly distributed. Therefore, increased impedance values are observed compared to other studied inhibitors' content. Also, such amount of $\mathrm{Ca}\left(\mathrm{NO}_{2}\right)_{2}$ inhibitor strengthens the passive film.

There is no significant difference observed in phasefrequency Bode plots of 0.99 and $7.91 \mathrm{~g} / \mathrm{L} \mathrm{NaCl}$ containing solution at $\left[\mathrm{Cl}^{-} / \mathrm{NO}_{2}{ }^{-}\right]=1.2$. The only differences are observed in range of frequency from 40 to $0.1 \mathrm{~Hz}$ compared to prior content of inhibitor. This result attributed that the film which had formed is homogenous because the maxima are shifted towards $-90^{\circ}$. It may be due to homogenous and uniform film deposition of steel rebar/solution interface enhancing the resistance of passive film against deterioration of steel rebar in $\mathrm{NaCl}$ containing solution [47].

The electrical equivalent circuit (EEC) is derived for all EIS plots presented in Figure 7. The steel rebar exposed without inhibitor in $0.99 \mathrm{~g} / \mathrm{L} \mathrm{NaCl}$ and inhibitor containing solution at $\left[\mathrm{Cl}^{-} / \mathrm{NO}_{2}{ }^{-}\right]=0.3$ in 0.99 and $7.91 \mathrm{~g} / \mathrm{L} \mathrm{NaCl}$ are shown in Figure $7(\mathrm{a})$. The EEC presented in this figure contain polarization resistance $\left(R_{\text {pore }}\right)$ and constant phase element (CPE) parallel to each other and these are in series with solution resistance $\left(R_{s}\right)$. This EEC is common for normal corrosion process which does not have any complex reaction on metal/solution interface [48]. On the other hand, the EEC shown in Figure $7(\mathrm{~b})$ is fitted for $\left[\mathrm{Cl}^{-} / \mathrm{NO}_{2}{ }^{-}\right]=0.00$ in $7.91 \mathrm{~g} / \mathrm{L} \mathrm{NaCl}$ as well as at $\left[\mathrm{Cl}^{-} / \mathrm{NO}_{2}{ }^{-}\right]=0.6$ and 1.2 in both concentrations of $\mathrm{NaCl}$, that is, 0.99 and $7.91 \mathrm{~g} / \mathrm{L}$ $\mathrm{NaCl}$. This EEC is containing Warburg impedance $(W)$ in series with $R_{\text {pore }}$ and CPE. The $W$ for $\left[\mathrm{Cl}^{-} / \mathrm{NO}_{2}{ }^{-}\right]=0.0$ in $7.91 \mathrm{~g} / \mathrm{L} \mathrm{NaCl}$ is attributed to deposition of corrosion products during exposure of steel rebar in this solution. This may be because the corrosion products diffuse from steel rebar surface because this solution did not contain inhibitor which is susceptible and initiates the corrosion easily. Presence of $W$ at $\left[\mathrm{Cl}^{-} / \mathrm{NO}_{2}{ }^{-}\right]=0.6$ and 1.2 in 0.99 and $7.91 \mathrm{~g} / \mathrm{L} \mathrm{NaCl}$ is attributed to adsorption of inhibitor on steel rebar surface and forming tiny layer of oxides film which causes diffusion. This layer is protective and increases the resistance for attack of $\mathrm{Cl}^{-}$ions on steel rebar surface.

The electrochemical extracted data of inhibitor and without inhibitor containing solution in 0.99 and $7.91 \mathrm{~g} / \mathrm{L}$ are shown in Table 3. $R_{s}$ is gradually decreased as amount of $\mathrm{NaCl}$ and inhibitor is increased because the solution becomes conductive. The conductivity of solution is increased due to the amount of ions increased. The more content of inhibitor and $\mathrm{NaCl}$ increases the amount of ions in solution resultant decrease in $R_{s}$ which is observed [45]. On the other 


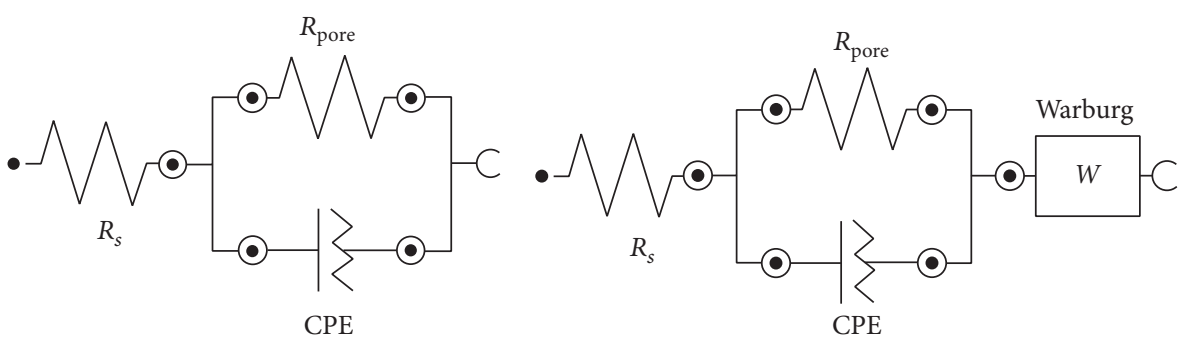

(a) $\left[\mathrm{Cl}^{-} / \mathrm{NO}_{2}^{-}\right]=0.0$ with $0.99 \mathrm{~g} / \mathrm{L} \mathrm{NaCl}$ and $\quad$ (b) $\left[\mathrm{Cl}^{-} / \mathrm{NO}_{2}^{-}\right]=0.0$ with $7.91 \mathrm{~g} / \mathrm{L} \mathrm{NaCl}$ and $\left[\mathrm{Cl}^{-} / \mathrm{NO}_{2}{ }^{-}\right]$ $\left[\mathrm{Cl}^{-} / \mathrm{NO}_{2}{ }^{-}\right]=0.3$ with 0.99 and $7.91 \mathrm{~g} / \mathrm{L} \mathrm{NaCl} \quad=0.6$ and 1.2 with 0.99 and $7.91 \mathrm{~g} / \mathrm{L} \mathrm{NaCl}$

FIGURE 7: Electrical equivalent circuit (ECC) with different concentrations of $\mathrm{NaCl}$ and $\left[\mathrm{Cl}^{-} / \mathrm{NO}_{2}^{-}\right]$in saturated $\mathrm{Ca}(\mathrm{OH})_{2}$ solution.

TABLE 3: Electrochemical parameters extracted after fitting of EIS plots in suitable EEC of steel rebar exposed in solutions.

\begin{tabular}{|c|c|c|c|c|c|c|c|}
\hline$\left[\mathrm{Cl}^{-} / \mathrm{NO}_{2}^{-}\right]$ & $\begin{array}{c}\text { Concentration } \\
\text { of } \mathrm{NaCl}(\mathrm{g} / \mathrm{L})\end{array}$ & $\begin{array}{l}R_{s} \\
(\Omega)\end{array}$ & $\begin{array}{c}R_{\text {pore }} \\
\left(\mathrm{k} \Omega \cdot \mathrm{cm}^{2}\right)\end{array}$ & $\begin{array}{c}\mathrm{CPE} \\
Y_{o}\left(1 \times 10^{-6}\right) \\
\left(\Omega^{-1} \cdot \mathrm{cm}^{-2} \mathrm{~s}^{-n}\right)\end{array}$ & $n$ & $\begin{array}{c}W \\
\left(1 \times 10^{-3}\right) \\
\left(\Omega \cdot \mathrm{cm}^{2} \mathrm{~s}^{0.5}\right) \\
\end{array}$ & $\begin{array}{c}\text { Efficiency } \\
(E \%)\end{array}$ \\
\hline \multirow{2}{*}{0.0} & 0.99 & 180.0 & 70.8 & 60.3 & 0.87 & - & - \\
\hline & 7.91 & 69.2 & 58.1 & 75.9 & 0.86 & 0.87 & - \\
\hline \multirow{2}{*}{0.3} & 0.99 & 60.9 & 219.0 & 34.4 & 0.93 & - & 67.67 \\
\hline & 7.91 & 38.0 & 170.0 & 45.1 & 0.91 & - & 65.82 \\
\hline \multirow{2}{*}{0.6} & 0.99 & 58.3 & 349.0 & 31.5 & 0.94 & 3.40 & 79.71 \\
\hline & 7.91 & 30.9 & 268.0 & 43.5 & 0.94 & 10.00 & 78.32 \\
\hline \multirow{2}{*}{1.2} & 0.99 & 51.6 & 497.0 & 30.6 & 0.94 & 3.90 & 85.75 \\
\hline & 7.91 & 23.1 & 347.0 & 42.6 & 0.94 & 11.20 & 83.26 \\
\hline
\end{tabular}

hand, it can be seen from Table 3 that, as the inhibitor is added in saturated $\mathrm{Ca}(\mathrm{OH})_{2}$ solution, $R_{\text {pore }}$ is gradually increased in both 0.99 and $7.91 \mathrm{~g} / \mathrm{L} \mathrm{NaCl}$ solutions. The inhibitor reduces the anodic surface area of steel rebar by mechanism of adsorption and forms oxides/passive film. The presence of $\mathrm{CPE}$ in place of capacitance is attributed to homogeneous adsorption of inhibitor. This inhibitor makes the surface uniform and homogeneous without any defect in films. The admittance $\left(Y_{o}\right)$ is decreased as concentration of inhibitor increased which correlates with the $R_{\text {pore }}$ results. $Y_{o}$ is always greater for $7.91 \mathrm{~g} / \mathrm{L} \mathrm{NaCl}$ than $0.99 \mathrm{~g} / \mathrm{L}$ because in such concentration, steel is prone to activate the surface for deterioration. From Table 3 it can be seen that the dispersion coefficient $(n)$ is becoming 0.9 and above which indicates that the surface is homogenised $[49,50]$ when inhibitor was added in solution. The " $n$ " is less than 0.9 in without inhibitor containing solution because the surface is inhomogeneous, defective, and susceptible to corrosion. The presence of $W$ in $7.91 \mathrm{~g} / \mathrm{L} \mathrm{NaCl}$ at $\left[\mathrm{Cl}^{-} / \mathrm{NO}_{2}{ }^{-}\right]=0.0$ is due to the formation of corrosion product (figure is not shown) while in case of inhibitor in $\left[\mathrm{Cl}^{-} / \mathrm{NO}_{2}{ }^{-}\right]$molar ratio of 0.6 and 1.2 with 0.99 and $7.91 \mathrm{~g} / \mathrm{L} \mathrm{NaCl}$ is attributed to adsorption of inhibitor on steel rebar surface which causes diffusion of passive film. The higher value of $W$ for $7.91 \mathrm{~g} / \mathrm{L}$ than $0.99 \mathrm{~g} / \mathrm{L} \mathrm{NaCl}$ when it contains inhibitor is caused by initiation of corrosion process and adsorption of inhibitor simultaneously. Therefore, this value is high.

The efficiency $(E \%)$ of inhibitor is calculated by following equation $[51,52]$ :

$$
E \%=\frac{R_{\text {pore }}-R_{\text {pore }}^{0}}{R_{\text {pore }}} \times 100,
$$

where $R_{\text {pore }}$ and $R_{\text {pore }}^{0}$ are polarization resistance with and without inhibitor, respectively. There is not so much difference observed in efficiency of 0.99 and $7.91 \mathrm{~g} / \mathrm{L} \mathrm{NaCl}$ solution while comparing with particular $\left[\mathrm{Cl}^{-} / \mathrm{NO}_{2}{ }^{-}\right]$ratios, that is, 0.3 to 1.2. At $\left[\mathrm{Cl}^{-} / \mathrm{NO}_{2}{ }^{-}\right]=0.3$, it is 67.67 and $65.82 \%$ for 0.99 and $7.91 \mathrm{~g} / \mathrm{L} \mathrm{NaCl}$, respectively. Such trend is also observed at $\left[\mathrm{Cl}^{-} / \mathrm{NO}_{2}{ }^{-}\right]=1.2$ which exhibited 85.75 and $83.26 \%$ for 0.99 and $7.91 \mathrm{~g} / \mathrm{L} \mathrm{NaCl}$ solution, respectively. This result indicates that the inhibitor significantly reduces the effect of $\mathrm{Cl}^{-}$ion even when it is in high amount. Once the $\mathrm{Ca}\left(\mathrm{NO}_{2}\right)_{2}$ is added in solution, it is adsorbed uniformly and forms protective oxides/passive film which sustains up to $7.91 \mathrm{~g} / \mathrm{L} \mathrm{NaCl}$ solution.

3.3. Potentiodynamic Studies. The potentiodynamic plots are shown in Figure 8. The steel rebar exposed in 0.99 and $7.91 \mathrm{~g} / \mathrm{L}$ $\mathrm{NaCl}$ containing saturated $\mathrm{Ca}(\mathrm{OH})_{2}$ solution is shown in Figure 8(a). This figure shows the characteristics of steel rebar without inhibitor containing solution; therefore, it exhibits higher current density. During anodic scanning of steel rebar in $0.99 \mathrm{~g} / \mathrm{L} \mathrm{NaCl}$ solution exhibits lesser current density than $7.91 \mathrm{~g} / \mathrm{L} \mathrm{NaCl}$ solution. It is due to less aggressiveness of $0.99 \mathrm{~g} / \mathrm{L} \mathrm{NaCl}$ which could not be able to deter the properties of passive film during exposure in saturated $\mathrm{Ca}(\mathrm{OH})_{2}$. On the other hand, the enhanced anodic current density of $7.91 \mathrm{~g} / \mathrm{L} \mathrm{NaCl}$ containing solution causes the localized attack 


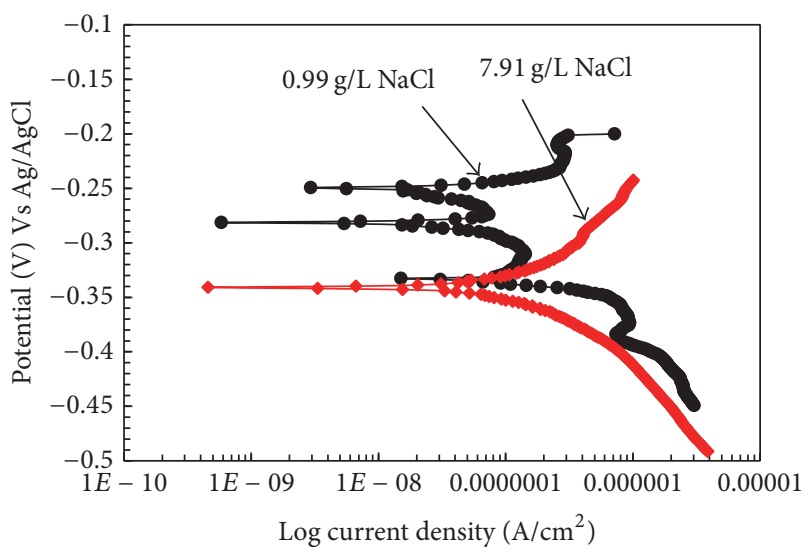

(a) Potentiodynamic plots without inhibitor

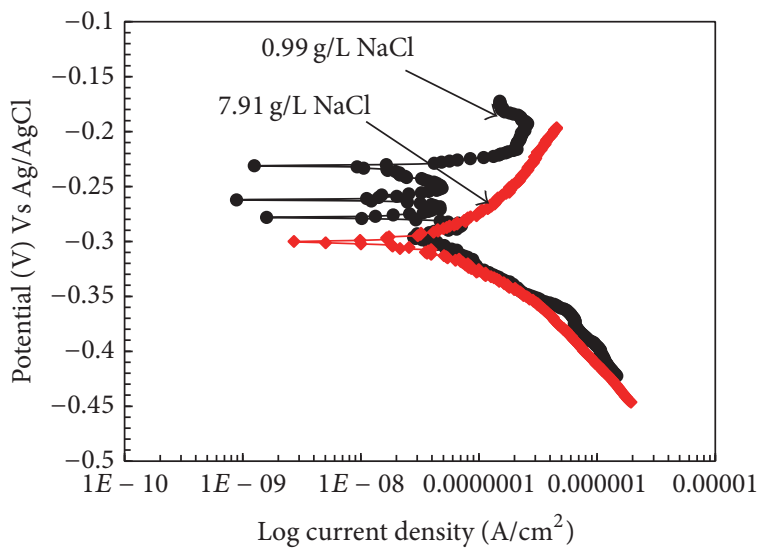

(c) Potentiodynamic plots at $\left[\mathrm{Cl}^{-} / \mathrm{NO}_{2}{ }^{-}\right]=0.6$

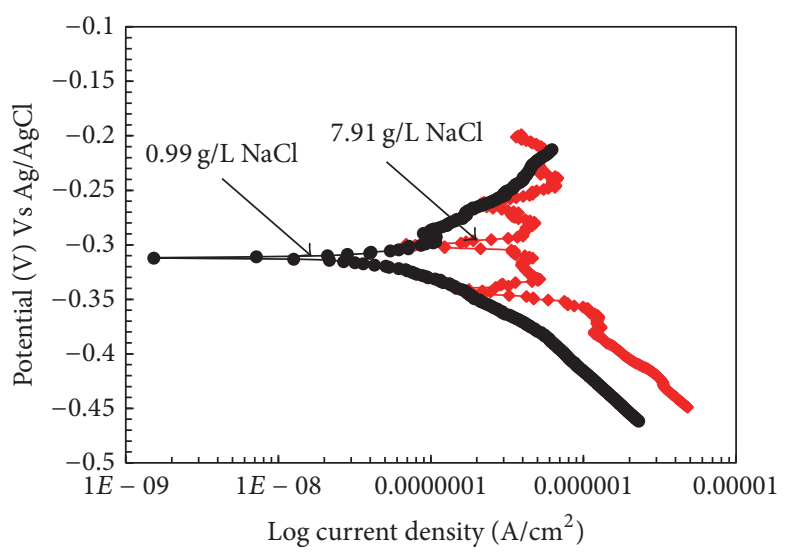

(b) Potentiodynamic plots at $\left[\mathrm{Cl}^{-} / \mathrm{NO}_{2}^{-}\right]=0.3$

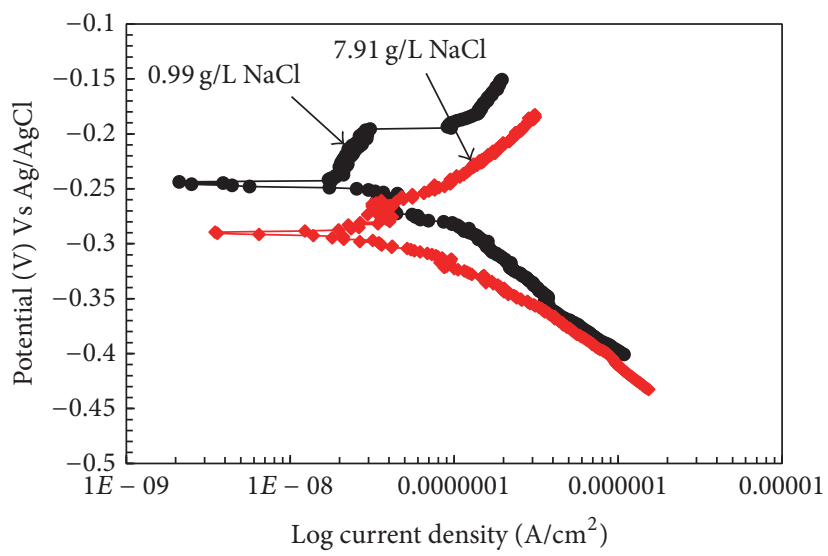

(d) Potentiodynamic plots at $\left[\mathrm{Cl}^{-} / \mathrm{NO}_{2}{ }^{-}\right]=1.2$

FIGURE 8: Potentiodynamic plots of steel rebar exposed in saturated $\mathrm{Ca}(\mathrm{OH})_{2}$ solution with different concentrations of $\mathrm{NaCl}$ and $\left[\mathrm{Cl}^{-} / \mathrm{NO}_{2}{ }^{-}\right]$.

on steel rebar resultant increase in its value. One interesting observation can be seen from anodic plots of $0.99 \mathrm{~g} / \mathrm{L} \mathrm{NaCl}$ containing solution that it exhibits 4 breakdown potential which may be attributed to mixed/metastable potential or formation of another phase of oxides on steel rebar/solution interface. The $0.99 \mathrm{~g} / \mathrm{L} \mathrm{NaCl}$ is not able to destroy the passive film but it can perturb the properties of passive film. The steel rebar generally forms protective oxide film when it is exposed in pore/saturated $\mathrm{Ca}(\mathrm{OH})_{2}$ solution without any impurities. Three breakdown potential of steel rebar exposed in $0.99 \mathrm{~g} / \mathrm{L} \mathrm{NaCl}$ exhibits nobler than $7.91 \mathrm{~g} / \mathrm{L} \mathrm{NaCl}$ containing solution. The corrosion potential $\left(E_{\text {corr }}\right)$ of steel rebar exposed in $0.99 \mathrm{~g} / \mathrm{L} \mathrm{NaCl}$ is nobler (positive) than $7.91 \mathrm{~g} / \mathrm{L} \mathrm{NaCl}$ which may be attributed to the formation of different phases of oxides. The cathodic plots show oxygen reduction reaction where the cathodic current of $0.99 \mathrm{~g} / \mathrm{L} \mathrm{NaCl}$ is a little bit more than $7.91 \mathrm{~g} / \mathrm{L} \mathrm{NaCl}$ solution. It may be the prior form oxide film which gets reduced during anodic scanning deposited on steel surface [53]. Therefore, the steel rebar exposed in $0.99 \mathrm{~g} / \mathrm{L} \mathrm{NaCl}$ exhibits breakdown potential during anodic scanning.

Once the inhibitor was added in saturated $\mathrm{Ca}(\mathrm{OH})_{2}$ with 0.99 and $7.99 \mathrm{~g} / \mathrm{L} \mathrm{NaCl}$ solution at $\left[\mathrm{Cl}^{-} / \mathrm{NO}_{2}{ }^{-}\right]=0.3$, the anodic current density is shifted towards lower side
(Figure 8(b)) compared to without inhibitor containing solution. It means that the $\mathrm{Ca}\left(\mathrm{NO}_{2}\right)_{2}$ is controlling the deterioration of steel rebar. $E_{\text {corr }}$ is also shifted towards positive (nobler) side than without inhibitor containing solution in both studied $\mathrm{NaCl}$ (Figure 8(b)). In case of $7.91 \mathrm{~g} / \mathrm{L} \mathrm{NaCl}$ containing solution a lot of fluctuated breakdown potential is observed. It may be attributed to adsorption of inhibitor on steel surface and at the same time the $\mathrm{Cl}^{-}$ions violating the passive film. Therefore, there is chance of competition between $\mathrm{Cl}^{-}$ions and priorly formed oxides film resultant fluctuated breakdown potential which is observed. The anodic current density of $0.99 \mathrm{~g} / \mathrm{L} \mathrm{NaCl}$ containing solution at $\left[\mathrm{Cl}^{-} / \mathrm{NO}_{2}{ }^{-}\right]=0.3$ is so far from $7.91 \mathrm{~g} / \mathrm{L} \mathrm{NaCl}$ solution. This result indicates the positive response of $\mathrm{Ca}\left(\mathrm{NO}_{2}\right)_{2}$ inhibitor. Thus, it was decided to increase the concentration of $\mathrm{Ca}\left(\mathrm{NO}_{2}\right)_{2}$ inhibitor further in present study. The cathodic current density for $0.99 \mathrm{~g} / \mathrm{L} \mathrm{NaCl}$ at $\left[\mathrm{Cl}^{-} / \mathrm{NO}_{2}{ }^{-}\right]=0.3$ is lesser than $7.91 \mathrm{~g} / \mathrm{L} \mathrm{NaCl}$ solution.

The steel rebar exposed in $\mathrm{NaCl}$ contaminated $\mathrm{Ca}(\mathrm{OH})_{2}$ solution at $\left[\mathrm{Cl}^{-} / \mathrm{NO}_{2}{ }^{-}\right]=0.6$ and their potentiodynamic plots are shown Figure 8(c). The anodic current density of $0.99 \mathrm{~g} / \mathrm{L} \mathrm{NaCl}$ containing solution is lesser than $7.91 \mathrm{~g} / \mathrm{L} \mathrm{NaCl}$ solution. The increased amount of $\mathrm{Ca}\left(\mathrm{NO}_{2}\right)_{2}$ inhibitor makes the steel surface less conductive due to formation of oxides 
TABLE 4: Electrochemical parameters were extracted after fitting of potentiodynamic plots in Tafel region.

\begin{tabular}{|c|c|c|c|c|c|}
\hline$\left[\mathrm{Cl}^{-} / \mathrm{NO}_{2}^{-}\right]$ & Concentration of $\mathrm{NaCl}(\mathrm{g} / \mathrm{L})$ & $\begin{array}{c}E_{\text {corr }}(\mathrm{mV}) \\
\text { Vs Ag/AgCl }\end{array}$ & $\begin{array}{c}I_{\text {corr }} \\
\left(\mu \mathrm{A} / \mathrm{cm}^{2}\right)\end{array}$ & $\begin{array}{c}R_{\text {pore }} \\
\left(\mathrm{k} \Omega \cdot \mathrm{cm}^{2}\right)\end{array}$ & $\begin{array}{c}\text { Corrosion rate } \\
(\mu \mathrm{m} / \text { year })\end{array}$ \\
\hline \multirow{2}{*}{0.0} & 0.99 & -335 & 1.29 & 111.10 & 14.99 \\
\hline & 7.91 & -350 & 2.94 & 102.45 & 34.16 \\
\hline \multirow{2}{*}{0.3} & 0.99 & -263 & 0.33 & 217.77 & 3.83 \\
\hline & 7.91 & -310 & 0.29 & 154.19 & 3.37 \\
\hline \multirow{2}{*}{0.6} & 0.99 & -253 & 0.021 & 259.66 & 0.24 \\
\hline & 7.91 & -301 & 0.16 & 230.69 & 1.86 \\
\hline \multirow{2}{*}{1.2} & 0.99 & -230 & 0.009 & 892.59 & 0.10 \\
\hline & 7.91 & -291 & 0.14 & 272.86 & 1.63 \\
\hline
\end{tabular}

film. The oxide films may have less conductivity; therefore, the more fluctuated/breakdown potential/current at anodic polarization is observed in $0.99 \mathrm{~g} / \mathrm{L} \mathrm{NaCl}$ while such type of observation is not found in $7.91 \mathrm{~g} / \mathrm{L} \mathrm{NaCl}$. The high amount of $\mathrm{NaCl}$, that is, $7.91 \mathrm{~g} / \mathrm{L}$, increased the conductivity of passive film being formed on steel rebar/solution interface which inhibited the formation of protective oxide films [54]. In case of $0.99 \mathrm{~g} / \mathrm{L} \mathrm{NaCl}$ solution at $\left[\mathrm{Cl}^{-} / \mathrm{NO}_{2}{ }^{-}\right]=0.6$ whenever breakdown potential is observed, all are nobler than $7.91 \mathrm{~g} / \mathrm{L}$ $\mathrm{NaCl} E_{\text {corr }}$ value. The $0.99 \mathrm{~g} / \mathrm{L} \mathrm{NaCl}$ exhibit passive region at $19.2 \mu \mathrm{A} / \mathrm{cm}^{2}$ from -220 to $-190 \mathrm{mV}$ applied potential ranges. Such type of observation is not found in case of $7.91 \mathrm{~g} / \mathrm{L} \mathrm{NaCl}$ solution. This result indicates that increased concentration of $\mathrm{Ca}\left(\mathrm{NO}_{2}\right)_{2}$ inhibitor worked significantly in reduction of corrosion of steel rebar in $\mathrm{NaCl}$ contaminated $\mathrm{Ca}(\mathrm{OH})_{2}$, solution. The cathodic current density for both concentrations of $\mathrm{NaCl}$ is almost identical. There is no significant difference observed in 0.99 and $7.91 \mathrm{~g} / \mathrm{L} \mathrm{NaCl}$ solution at $\left[\mathrm{Cl}^{-} / \mathrm{NO}_{2}{ }^{-}\right]$ $=0.6$. Both $\mathrm{NaCl}$ concentrations show oxygen reduction reaction at cathodic scanning.

The significant effect of $\mathrm{Ca}\left(\mathrm{NO}_{2}\right)_{2}$ can be observed when its concentration is increased at specified $\mathrm{NaCl}$ content. The molar ratio $\left[\mathrm{Cl}^{-} / \mathrm{NO}_{2}{ }^{-}\right]=1.2$ is sufficient to reduce the corrosion of steel rebar in 0.99 and $7.91 \mathrm{~g} / \mathrm{L} \mathrm{NaCl}$ containing solution. The anodic scanning plots indicate the shifting of current density towards lower side than other studied content of $\mathrm{Ca}\left(\mathrm{NO}_{2}\right)_{2}$ inhibitor in both concentrations of $\mathrm{NaCl}$ (Figure $8(\mathrm{~d})$ ). The $0.99 \mathrm{~g} / \mathrm{L} \mathrm{NaCl}$ solution exhibited nobler $E_{\text {corr }}$ and less anodic current density than $7.91 \mathrm{~g} / \mathrm{L}$ $\mathrm{NaCl}$. In both contents of $\mathrm{NaCl}$, steel rebar shows pitting tendency and it may be due to formation of low conductive passive film during anodic scanning. The applied potential perturbs the passive film properties resultant pitting which is observed. The two passive regions are observed in $0.99 \mathrm{~g} / \mathrm{L}$ $\mathrm{NaCl}$ solution at different anodic scanning. The interesting result can be seen from Figure 8(d) that once the passive film is formed and potential is continuously applied during anodic scanning, sudden increase in current is observed. It may be during anodic applied potential that the surface forms strong passive film but the $\mathrm{Cl}^{-}$ions in solution locally attack surface and weaken the passive film. Thus, sudden increase in anodic current is observed after formation of passive film on steel rebar surface in $0.99 \mathrm{~g} / \mathrm{L} \mathrm{NaCl}$ solution (Figure $8(\mathrm{~d})$ ). There are no significant differences observed in cathodic polarization studies of steel rebar exposed in 0.99 and $7.91 \mathrm{~g} / \mathrm{L}$ $\mathrm{NaCl}$ at $\left[\mathrm{Cl}^{-} / \mathrm{NO}_{2}{ }^{-}\right]=1.2$. It may be due to the formation of less conducting, stable oxides film after exposure of steel at $\left[\mathrm{Cl}^{-} / \mathrm{NO}_{2}{ }^{-}\right]=1.2$ in 0.99 and $7.91 \mathrm{~g} / \mathrm{L} \mathrm{NaCl}$ solution which does not allow reducing the formed oxide films.

There is competition between $\mathrm{Cl}^{-}$and $\mathrm{NO}_{2}{ }^{-}$ions on steel rebar/solution interface. The $\mathrm{NO}_{2}{ }^{-}$ion is strong oxidizing chemical which transformed the unstable oxide (due to attack of $\mathrm{Cl}^{-}$ions) into their stable form in chloride contaminated $\mathrm{Ca}(\mathrm{OH})_{2}$ solution. Thus, for proper mitigation of steel rebar from corrosion, sufficient amount of $\mathrm{Ca}\left(\mathrm{NO}_{2}\right)_{2}$ is required. In this study, to diminish the corrosion of steel rebar exposed in 0.99 and $7.91 \mathrm{~g} / \mathrm{L} \mathrm{NaCl}$ solution, $\left[\mathrm{Cl}^{-} / \mathrm{NO}_{2}{ }^{-}\right]=1.2$ molar ratio is required for transformation of unstable iron oxides into their stable form.

The electrochemical parameters are extracted after fitting of potentiodynamic plots in Tafel regions. In inhibitor containing potentiodynamic plots, it is very hard to identify the Tafel regions but we try to select the regions and extract fitted data. The extracted data is shown in Table 4. The $\mathrm{NaCl}$ is aggressive agents for deterioration of steel which locally attack on steel rebar and initiate corrosion process. Due to aggressiveness of $\mathrm{Cl}^{-}$ion, it induces the steel for localized corrosion resultant and $E_{\text {corr }}$ may increase (active). Such type of observation can be seen from Table 4 that $E_{\text {corr }}$ of without inhibitor containing solution such as $\left[\mathrm{Cl}^{-} / \mathrm{NO}_{2}{ }^{-}\right]=0.0$ in 0.99 and $7.91 \mathrm{~g} / \mathrm{L} \mathrm{NaCl}$ is higher than inhibitor containing solution. The steel rebar exposed in 0.99 and $7.91 \mathrm{~g} / \mathrm{L} \mathrm{NaCl}$ exhibits their $E_{\text {corr }}$ at -335 and $-350 \mathrm{mV}$, respectively. As the inhibitor added, $E_{\text {corr }}$ is shifted at -230 and $-291 \mathrm{mV}$ for 0.99 and $7.91 \mathrm{~g} / \mathrm{L} \mathrm{NaCl}$ at $\left[\mathrm{Cl}^{-} / \mathrm{NO}_{2}{ }^{-}\right]=1.2$, respectively. The steel rebar exposed in $0.99 \mathrm{~g} / \mathrm{L} \mathrm{NaCl}$ at $\left[\mathrm{Cl}^{-} / \mathrm{NO}_{2}{ }^{-}\right]=0.0$ and 1.2 exhibits $105 \mathrm{mV}$ difference. The steel rebar has difference in $E_{\text {corr }}$ more than $\pm 85 \mathrm{mV}$ versus saturated calomel electrode (SCE) when it is exposed in inhibitor; such type of inhibitor works as anodic or cathodic inhibitor [55-58]. If difference is in between $\pm 85 \mathrm{mV}$ then it works as mixed type inhibitor. This result confirms that $\mathrm{Ca}\left(\mathrm{NO}_{2}\right)_{2}$ works as anodic inhibitor which correlate the result of earlier published papers which was stated for acidic inhibitor containing solution [12, 40]. However, the corrosion current density $\left(I_{\text {corr }}\right)$ of inhibitor is significantly reduced from $1.29 \mu \mathrm{A} / \mathrm{cm}^{2}$ to $0.009 \mu \mathrm{A} / \mathrm{cm}^{2}$ in $0.99 \mathrm{~g} / \mathrm{L} \mathrm{NaCl}$ at $\left[\mathrm{Cl}^{-} / \mathrm{NO}_{2}{ }^{-}\right]=0.0$ to 1.2 . The reduction in $I_{\text {corr }}$ is attributed to the formation of protective 
oxides/hydroxide film by inhibitor which transformed unstable oxides into their stable form. The steel rebar exposed in without inhibitor containing solution exhibited lower $R_{\text {pore }}$ which indicates the deterioration of steel rebar due to presence of $\mathrm{Cl}^{-}$ion in solution. The $\mathrm{Cl}^{-}$ions attack steel rebar and enhance the corrosion process. In this solution, there is no other inhibitive agent which diminishes the effect of $\mathrm{Cl}^{-}$ion. Thus, initially whenever the $\mathrm{OH}^{-}$ions were generated from $\mathrm{Ca}(\mathrm{OH})_{2}$ solution, they react with steel and form oxides film which becomes susceptible. It may be this film that is conductive and easily destroyed by $\mathrm{Cl}^{-}$ion. Here, the $\mathrm{Cl}^{-}$ion may be dominant over $\mathrm{OH}^{-}$ion and initiated the corrosion process. Therefore, $R_{\text {pore }}$ is very less but as inhibitor was added and its value gradually increased. The increased value in $R_{\text {pore }}$ with inhibitor indicates the positive response of $\mathrm{Ca}\left(\mathrm{NO}_{2}\right)_{2}$ in formation of protective oxides film than without inhibitor containing solution. $R_{\text {pore }}$ is increased from $111.10 \mathrm{k} \Omega \cdot \mathrm{cm}^{2}$ for $0.99 \mathrm{~g} / \mathrm{L} \mathrm{NaCl}$ at $\left[\mathrm{Cl}^{-} / \mathrm{NO}_{2}{ }^{-}\right]=0.0$ to $892.59 \mathrm{k} \Omega \cdot \mathrm{cm}^{2}$ at $\left[\mathrm{Cl}^{-} / \mathrm{NO}_{2}{ }^{-}\right]=1.2$. The corrosion rate $(\mu \mathrm{m} / \mathrm{y})$ was calculated by using following equation [59]:

$$
\text { Corrosion rate }(\mu \mathrm{m} / \mathrm{y})=\frac{3.27 \times I_{\text {corr }} \times \mathrm{EW}}{d},
$$

where the corrosion rate is micrometer per year $(\mu \mathrm{m} / \mathrm{y})$, $I_{\text {corr }}$ in $\mu \mathrm{A} / \mathrm{cm}^{2} . I_{\text {corr }}$ was obtained by dividing total surface area of the working electrode into the corrosion current $(\mu \mathrm{A})$, EW represents the equivalent weight (g/mole), and $d$ is density $\left(\mathrm{g} / \mathrm{cm}^{3}\right)$ of iron. The corrosion rate is significantly reduced when $\mathrm{Ca}\left(\mathrm{NO}_{2}\right)_{2}$ is added in $\mathrm{NaCl}$ contaminated $\mathrm{Ca}(\mathrm{OH})_{2}$ solution due to formation of protective and adherent oxides/hydroxides film on steel rebar/solution interface. The $\mathrm{Ca}\left(\mathrm{NO}_{2}\right)_{2}$ block the active site of steel rebar in $\mathrm{NaCl}$ contaminated $\mathrm{Ca}(\mathrm{OH})_{2}$ solution and reduce the attack of $\mathrm{Cl}^{-}$ ion. The inhibitor may transform unstable oxides (due to reaction of $\mathrm{Cl}^{-}$ion with steel and forming $\mathrm{Cl}^{-}$bearing iron oxides/hydroxides) into stable oxides/hydroxides. Therefore, the corrosion rate of steel rebar is significantly reduced from 14.99 and $34.16 \mu \mathrm{m} /$ year in 0.99 and $7.91 \mathrm{~g} / \mathrm{L} \mathrm{NaCl}$ at $\left[\mathrm{Cl}^{-} / \mathrm{NO}_{2}{ }^{-}\right]=0.0$ to 0.10 and $1.63 \mu \mathrm{m} /$ year at $\left[\mathrm{Cl}^{-} / \mathrm{NO}_{2}{ }^{-}\right]=$ 1.2 , respectively (Table 4 ).

\section{Discussion}

The steel rebar exposed in $\mathrm{Ca}\left(\mathrm{NO}_{2}\right)_{2}$ solution with $\mathrm{NaCl}$ is protected from corrosion. The mechanism of effect of $\mathrm{Ca}\left(\mathrm{NO}_{2}\right)_{2}$ inhibitor to mitigate the corrosion of steel rebar is as follows [42]:

$$
\begin{gathered}
\mathrm{Fe} \longrightarrow \mathrm{Fe}^{2+}+2 \mathrm{e}^{-} \\
2 \mathrm{H}_{2} \mathrm{O}+\mathrm{O}_{2}+4 \mathrm{e}^{-} \longrightarrow 4 \mathrm{OH}^{-} \\
2 \mathrm{Fe}^{2+}+2 \mathrm{OH}^{-}+2 \mathrm{NO}_{2}^{-} \longrightarrow 2 \mathrm{NO}+\mathrm{Fe}_{2} \mathrm{O}_{3}+\mathrm{H}_{2} \mathrm{O}
\end{gathered}
$$

Initially the $\mathrm{Cl}^{-}$ion reacts with iron and forms ferrous ion $\left(\mathrm{Fe}^{2+}\right)(3)$. This is unstable and enhances the corrosion process but when $\mathrm{Ca}\left(\mathrm{NO}_{2}\right)_{2}$ inhibitor was added in solution, it transformed $\mathrm{Fe}^{2+}$ ion into $\mathrm{Fe}^{3+}$ (ferric) ion such as $\mathrm{Fe}_{2} \mathrm{O}_{3}$ (5). A considerable research had been carried out to mitigate the corrosion of steel rebar by adding $\mathrm{Ca}\left(\mathrm{NO}_{2}\right)_{2}$, that is, nitrite based corrosion inhibitor in saturated $\mathrm{Ca}(\mathrm{OH})_{2}$ solution $[8,24,38,60-65]$. Nitrite is a strong oxidizing agent which transformed $\mathrm{Fe}^{2+}$ into $\mathrm{Fe}^{3+}$ at anodic site of steel. This $\mathrm{Fe}^{3+}$ ion precipitated out and blocked the active site of steel and formed passive film [21]. Page et al. have reported the $\mathrm{Ca}\left(\mathrm{NO}_{2}\right)_{2}$ works effectively if water/cement $(\mathrm{w} / \mathrm{c})$ ratio is less than 0.5 and $\left[\mathrm{Cl}^{-} / \mathrm{NO}_{2}{ }^{-}\right]$ratio is in between 0.5 to 1 but in present study it is $1.2[1,38]$. In this study, we simulated the pore solution and directly exposed the steel rebar. There was no onset time required to react the $\mathrm{Cl}^{-}$ion with steel rebar such as in concrete condition. In case of concrete, time is required to penetrate the $\mathrm{Cl}^{-}$ion through pores of concrete and later it initiates the corrosion of steel rebar. The less than $0.5 \mathrm{w} / \mathrm{c}$ ratio reduces the porosity of concrete and increases the strength of it through where there is very little chance of ingress of the $\mathrm{Cl}^{-}$ion, moisture, and so forth. The $\mathrm{Cl}^{-}$ion is the main culprit which causes the corrosion of steel rebar in concrete environment. Therefore, in present study, the $\left[\mathrm{Cl}^{-} / \mathrm{NO}_{2}{ }^{-}\right]=1.2$ which is greater than that earlier reported in concrete environment $[1,38]$.

\section{Conclusions}

From the above results and discussion, it is found that $\mathrm{Ca}\left(\mathrm{NO}_{2}\right)_{2}$ inhibitor worked significantly in reducing the initiation of corrosion of steel rebar in $\mathrm{NaCl}$ contaminated $\mathrm{Ca}(\mathrm{OH})_{2}$ solution. The $85.75 \%$ efficiency of inhibitor in $0.99 \mathrm{~g} / \mathrm{L} \mathrm{NaCl}$ at $\left[\mathrm{Cl}^{-} / \mathrm{NO}_{2}{ }^{-}\right]=1.2$ indicates the nitrite based corrosion inhibitor reducing the corrosion of steel even in its low amount in simulated condition. During anodic polarization studies the inhibitor containing plots exhibited a lot of breakdown potential because different phases of protective oxides/passive films had formed which may be protective and adherent. From this study it is also confirmed that $\mathrm{Ca}\left(\mathrm{NO}_{2}\right)_{2}$ inhibitor works as anodic inhibitor in $0.99 \mathrm{~g} / \mathrm{L}$ $\mathrm{NaCl}$ solution at $\left[\mathrm{Cl}^{-} / \mathrm{NO}_{2}{ }^{-}\right]=1.2$. As the concentration of $\mathrm{NaCl}$ increased the corrosion rate of steel increased due to aggressiveness of $\mathrm{Cl}^{-}$ion which locally attacks anodic site of steel rebar.

\section{Competing Interests}

The authors declare that there is no conflict of interests regarding the publication of this paper.

\section{Authors' Contributions}

Dr. Ryu and Singh conducted the experiments and wrote the initial draft of the manuscript. Dr. Ryu also designed the project and analyzed the data. Dr. Lee and Park reviewed and contributed to the final revised manuscript. All authors contributed to the analysis of the data and read the final paper.

\section{Acknowledgments}

This research was supported by the research grant from Korea Agency for Infrastructure Technology Advancement funded 
by the Ministry of Land, Infrastructure and Transport of the Korean Government (Project no. 16CTAP-C115067-01000000).

\section{References}

[1] C. L. Page, Durability of Concrete and Cement Composites, Edited by C. L. Page and M. M. Page, Woodhead Publishing Limited, Cambridge, UK, 2007.

[2] D. A. Hausmann, "Steel corrosion in concrete-how does it occur," Materials Protection, vol. 6, pp. 19-23, 1967.

[3] V. K. Gouda, "Corrosion and corrosion inhibition of reinforcing steel: I. immersed in alkaline solutions," British Corrosion Journal, vol. 5, no. 5, pp. 198-203, 1970.

[4] V. K. Gouda and W. Y. Halaka, "Corrosion and corrosion inhibition of reinforcing steel II. Embedded in concrete," British Corrosion Journal, vol. 5, no. 5, pp. 204-208, 1970.

[5] L. Bertolini, F. Bolzoni, T. Pastore, and P. Pedeferri, "Behaviour of stainless steel in simulated concrete pore solution," British Corrosion Journal, vol. 31, no. 3, pp. 218-222, 1996.

[6] M. Moreno, W. Morris, M. G. Alvarez, and G. S. Duffó, "Corrosion of reinforcing steel in simulated concrete pore solutions effect of carbonation and chloride content," Corrosion Science, vol. 46, no. 11, pp. 2681-2699, 2004.

[7] K. Y. Ann and H.-W. Song, "Chloride threshold level for corrosion of steel in concrete," Corrosion Science, vol. 49, no. 11, pp. 4113-4133, 2007.

[8] Z. H. Dong, W. Shi, and X. P. Guo, "Initiation and repassivation of pitting corrosion of carbon steel in carbonated concrete pore solution," Corrosion Science, vol. 53, no. 4, pp. 1322-1330, 2011.

[9] C.-Q. Ye, R.-G. Hu, S.-G. Dong et al., "EIS analysis on chlorideinduced corrosion behavior of reinforcement steel in simulated carbonated concrete pore solutions," Journal of Electroanalytical Chemistry, vol. 688, pp. 275-281, 2013.

[10] Y. T. Tan, S. L. Wijesinghe, and D. J. Blackwood, “The inhibitive effect of bicarbonate and carbonate ions on carbon steel in simulated concrete pore solution," Corrosion Science, vol. 88, pp. 152-160, 2014.

[11] K. K. Sagoe-Crentsil, F. P. Glasser, and J. T. S. Irvine, "Electrochemical characteristics of reinforced concrete corrosion as determined by impedance spectroscopy," British Corrosion Journal, vol. 27, no. 2, pp. 113-118, 1992.

[12] H. Ryu, J. K. Singh, H. Lee, M. A. Ismail, and W. Park, "Effect of $\mathrm{LiNO}_{2}$ inhibitor on corrosion characteristics of steel rebar in saturated $\mathrm{Ca}(\mathrm{OH})_{2}$ solution containing $\mathrm{NaCl}$ : an electrochemical study," Construction and Building Materials, vol. 133, pp. 387396, 2017.

[13] W. Hart and H. Voshardt, Influence of $\mathrm{Ca}\left(\mathrm{NO}_{2}\right)_{2}$ on Seawater Corrosion of Reinforcing Steel in Concrete, Part 2, Corrosion/81, Publication no. 52, NACE, Toronto, Canada, 1981.

[14] N. S. Berke and W. R. Grace, "The effects of calcium nitrite and mix design on the corrosion resistance of steel in concrete, part 1," Corrosion/85, NACE, Boston, Mass, USA, 1985.

[15] N. S. Berke and W. R. Grace, The Effects of Calcium Nitrite and Mix Design on the Corrosion Resistance of Steel in Concrete, Part 2, Publ. no. 273, Corrosion/87, NACE, San Francisco, Calif, USA, 1987.

[16] F. Martinez and R. Troconis, "Efectos de los inhibidores $\mathrm{ZnO}$ y $\mathrm{Ca}\left(\mathrm{NO}_{2}\right)_{2}$ y del agua del Lago de Maracaibo en las propiedades fisico quimicas del concreto," in Memorias del II Congresso
Iberoamericano de Corrosion y Proteccion, vol. I, pp. 397-403, Maracaibo, Venezuela, November 1986.

[17] T. de Rincon, O. Uso de los Inhibidores para el Control del Acero de Refuerzo de Concreto, VIII Reunion Latinoamericana de Electroquimica y Corrosion, Huerta Grande, Cordoba, Argentina, 1988.

[18] R. J. Craig and L. E. Wood, Effectiveness of Corrosion Inhibitors and Their Influence on the Physical Properties of Portland Cement Mortars, Highway Research Record No. 328, Highway Research Board, 1970.

[19] G. Trabanelli, "Corrosion inhibitors," in Corrosion Mechanisms, F. Mansfeld, Ed., chapter 3, Marcel Dekker, New York, NY, USA, 1986.

[20] P. Gu, S. Elliott, R. Hristova, J. J. Beaudoin, R. Brousseau, and B. Baldock, "A study of corrosion inhibitor performance in chloride contaminated concrete by electrochemical impedance spectroscopy," ACI Materials Journal, vol. 94, no. 5, pp. 385-395, 1997.

[21] J. M. Gaidis, "Chemistry of corrosion inhibitors," Cement and Concrete Composites, vol. 26, no. 3, pp. 181-189, 2004.

[22] J. S. Reou and K. Y. Ann, “The electrochemical assessment of corrosion inhibition effect of calcium nitrite in blended concretes," Materials Chemistry and Physics, vol. 109, no. 2-3, pp. 526-533, 2008.

[23] O. S. B. Al-Amoudi, M. Maslehuddin, A. N. Lashari, and A. A. Almusallam, "Effectiveness of corrosion inhibitors in contaminated concrete," Cement and Concrete Composites, vol. 25, no. 4-5, pp. 439-449, 2003.

[24] K. Y. Ann, H. S. Jung, H. S. Kim, S. S. Kim, and H. Y. Moon, "Effect of calcium nitrite-based corrosion inhibitor in preventing corrosion of embedded steel in concrete," Cement and Concrete Research, vol. 36, no. 3, pp. 530-535, 2006.

[25] V. T. Ngala, C. L. Page, and M. M. Page, "Corrosion inhibitor systems for remedial treatment of reinforced concrete. Part 1 : calcium nitrite," Corrosion Science, vol. 44, no. 9, pp. 2073-2087, 2002.

[26] G. Batis, K. K. Sideris, and P. Pantazopoulou, "Influence of calcium nitrite inhibitor on the durability of mortars under contaminated chloride and sulphate environments," Anti-Corrosion Methods and Materials, vol. 51, no. 2, pp. 112-120, 2004.

[27] L. Abosrra, M. Youseffi, and A. F. Ashour, "Effectiveness of calcium nitrite in retarding corrosion of steel in concrete," International Journal of Concrete Structures and Materials, vol. 5, pp. 65-73, 2011.

[28] M. Ramasubramanian, B. S. Haran, S. Popova, B. N. Popov, M. F. Petrou, and R. E. White, "Inhibiting action of calcium nitrite on carbon steel rebars," Journal of Materials in Civil Engineering, vol. 13, no. 1, pp. 10-17, 2001.

[29] H. Justnes, "Corrosion inhibitors for reinforced concrete," in Proceedings of the 7th CANMET/ACI International Conference on Durability of Concrete, ACI SP 234-4, pp. 53-70, Montreal, Canada, 2006.

[30] W. Medford, "Testing calcium nitrite corrosion inhibitor in concrete," Transportation Research Record, vol. 1795, pp. 62-65, 2014.

[31] S. M. Trépanier, B. B. Hope, and C. M. Hansson, "Corrosion inhibitors in concrete: part III. Effect on time to chlorideinduced corrosion initiation and subsequent corrosion rates of steel in mortar," Cement and Concrete Research, vol. 31, no. 5, pp. 713-718, 2001. 
[32] M. Ormellese, M. Berra, F. Bolzoni, and T. Pastore, "Corrosion inhibitors for chlorides induced corrosion in reinforced concrete structures," Cement and Concrete Research, vol. 36, no. 3, pp. 536-547, 2006.

[33] N. S. Berke and A. Rosenberg, "Technical review of calcium nitrite corrosion inhibitor in concrete," Transportation Research Record, no. 1211, pp. 18-27, 1989.

[34] N. S. Berke, "The effects of calcium nitrite and mix design on the corrosion resistance of steel in concrete (Part 2, LongTerm Results)," in Proceeding of the Corrosion 87 Symposium on Corrosion of Metals in Concrete, pp. 134-144, Houston, Tex, USA, 1987.

[35] H.-S. Ryu, J. K. Singh, H.-M. Yang, H.-S. Lee, and M. A. Ismail, "Evaluation of corrosion resistance properties of $\mathrm{N}$, $\mathrm{N}$ /-Dimethyl ethanolamine corrosion inhibitor in saturated $\mathrm{Ca}(\mathrm{OH})_{2}$ solution with different concentrations of chloride ions by electrochemical experiments," Construction and Building Materials, vol. 114, pp. 223-231, 2016.

[36] H.-S. Lee, J. K. Singh, M. A. Ismail, and C. Bhattacharya, "Corrosion resistance properties of aluminum coating applied by arc thermal metal spray in SAE J2334 solution with exposure periods," Metals, vol. 6, no. 3, article 55, 15 pages, 2016.

[37] H.-S. Lee, J. K. Singh, and J. H. Park, "Pore blocking characteristics of corrosion products formed on Aluminum coating produced by arc thermal metal spray process in $3.5 \mathrm{wt} . \% \mathrm{NaCl}$ solution," Construction and Building Materials, vol. 113, pp. 905916, 2016.

[38] N. S. Berke and M. C. Hicks, "Predicting long-term durability of steel reinforced concrete with calcium nitrite corrosion inhibitor," Cement and Concrete Composites, vol. 26, no. 3, pp. 191-198, 2004.

[39] W. D. Collins, R. E. Weyers, and I. L. Al-Qadi, "Chemical treatment of corroding steel reinforcement after removal of chloride-contaminated concrete," Corrosion, vol. 49, no. 1, pp. 74-88, 1993.

[40] O. Girèienë, M. Samulevièienë, A. Sudavièius, R. Ramanauskas, and L. Lapuchin, "Efficiency of steel corrosion inhibitor calcium nitrite in alkaline solutions and concrete structures," Chemija, vol. 16, pp. 1-6, 2005.

[41] M. Saremi and E. Mahallati, "A study on chloride-induced depassivation of mild steel in simulated concrete pore solution," Cement and Concrete Research, vol. 32, no. 12, pp. 1915-1921, 2002.

[42] V. Saraswathy and H.-W. Song, "Improving the durability of concrete by using inhibitors," Building and Environment, vol. 42, no. 1, pp. 464-472, 2007.

[43] H. Böhni and H. H. Uhlig, "Environmental factors affecting the critical pitting potential of aluminum," Journal of the Electrochemical Society, vol. 116, no. 7, pp. 906-910, 1969.

[44] D. A. Jones, Principles and Prevention of Corrosion, Macmillan, New York, NY, USA, 1st edition, 1992.

[45] A. Królikowski and J. Kuziak, "Impedance study on calcium nitrite as a penetrating corrosion inhibitor for steel in concrete," Electrochimica Acta, vol. 56, no. 23, pp. 7845-7853, 2011.

[46] N. Etteyeb, L. Dhouibi, M. Sanchez, C. Alonso, C. Andrade, and E. Triki, "Electrochemical study of corrosion inhibition of steel reinforcement in alkaline solutions containing phosphates based components," Journal of Materials Science, vol. 42, no. 13, pp. 4721-4730, 2007.

[47] J. K. Singh and D. D. N. Singh, "The nature of rusts and corrosion characteristics of low alloy and plain carbon steels in three kinds of concrete pore solution with salinity and different pH," Corrosion Science, vol. 56, pp. 129-142, 2012.

[48] M. Criado, S. Martínez-Ramirez, S. Fajardo, P. P. Gõmez, and J. M. Bastidas, "Corrosion rate and corrosion product characterisation using Raman spectroscopy for steel embedded in chloride polluted fly ash mortar," Materials and Corrosion, vol. 64, no. 5, pp. 372-380, 2013.

[49] C. Monticelli, A. Frignani, A. Balbo, and F. Zucchi, "Influence of two specific inhibitors on steel corrosion in a synthetic solution simulating a carbonated concrete with chlorides," Materials and Corrosion, vol. 62, no. 2, pp. 178-186, 2011.

[50] A.-N. Al-Negheimish, A. Alhozaimy, R. R. Hussain, R. Al-Zaid, J. K. Singh, and D. D. N. Singh, "Role of manganese sulfide inclusions in steel rebar in the formation and breakdown of passive films in concrete pore solutions," Corrosion, vol. 70, no. 1, pp. 74-86, 2014.

[51] H. Zheng, W. Li, F. Ma, and Q. Kong, "The performance of a surface-applied corrosion inhibitor for the carbon steel in saturated $\mathrm{Ca}(\mathrm{OH})_{2}$ solutions," Cement and Concrete Research, vol. 55, pp. 102-108, 2014.

[52] M. B. Valcarce and M. Vázquez, "Carbon steel passivity examined in solutions with a low degree of carbonation: the effect of chloride and nitrite ions," Materials Chemistry and Physics, vol. 115, no. 1, pp. 313-321, 2009.

[53] N. Imaz, M. Ostra, M. Vidal, J. A. Díez, M. Sarret, and E. GarcíaLecina, "Corrosion behaviour of chromium coatings obtained by direct and reverse pulse plating electrodeposition in $\mathrm{NaCl}$ aqueous solution," Corrosion Science, vol. 78, pp. 251-259, 2014.

[54] B. Cox and Y.-M. Wong, "Simulating porous oxide films on zirconium alloys," Journal of Nuclear Materials, vol. 218, no. 3, pp. 324-334, 1995.

[55] D. Jayaperumal, "Effects of alcohol-based inhibitors on corrosion of mild steel in hydrochloric acid," Materials Chemistry and Physics, vol. 119, no. 3, pp. 478-484, 2010.

[56] E. S. Ferreira, C. Giacomelli, F. C. Giacomelli, and A. Spinelli, "Evaluation of the inhibitor effect of L-ascorbic acid on the corrosion of mild steel," Materials Chemistry and Physics, vol. 83, no. 1, pp. 129-134, 2004.

[57] M. Yadav and S. Kumar, "Experimental, thermodynamic and quantum chemical studies on adsorption and corrosion inhibition performance of synthesized pyridine derivatives on N80 steel in $\mathrm{HCl}$ solution," Surface and Interface Analysis, vol. 46, no. 4, pp. 254-268, 2014.

[58] S. Kumar, D. Sharma, P. Yadav, and M. Yadav, "Experimental and quantum chemical studies on corrosion inhibition effect of synthesized organic compounds on N80 steel in hydrochloric acid," Industrial and Engineering Chemistry Research, vol. 52, no. 39, pp. 14019-14029, 2013.

[59] S. W. Dean, "Electrochemical methods of corrosion testing," in Electrochemical Techniques for Corrosion, R. Baboian, Ed., pp. 52-60, NACE, Houston, Tex, USA, 1977.

[60] B. B. Hope and S. V. Thompson, "Damage to concrete induced by calcium nitrite," ACI Materials Journal, vol. 92, no. 5, pp. 529531, 1993.

[61] L. Mammoliti, C. M. Hansson, and B. B. Hope, "Corrosion inhibitors in concrete Part II: effect on chloride threshold values for corrosion of steel in synthetic pore solutions," Cement and Concrete Research, vol. 29, no. 10, pp. 1583-1589, 1999.

[62] S. M. Trepanier, B. B. Hope, and G. M. Hansson, "Corrosion inhibitors in concrete: part III. Effect on time to chlorideinduced corrosion in initiation and subsequent corrosion rates 
of steel in concrete," Cement and Concrete Research, vol. 31, pp. 713-718, 2001.

[63] K. K. Sideris and A. E. Savva, "Durability of mixtures containing calcium nitrite based corrosion inhibitor," Cement and Concrete Composites, vol. 27, no. 2, pp. 277-287, 2005.

[64] M. B. Valcarce, C. López, and M. Vázquez, "The role of chloride, nitrite and carbonate ions on carbon steel passivity studied in simulating concrete pore solutions," Journal of the Electrochemical Society, vol. 159, no. 5, pp. C244-C251, 2012.

[65] Y. Zhou and Y. Zuoz, "The passivation behavior of mild steel in $\mathrm{CO}_{2}$ saturated solution containing nitrite anions," Journal of the Electrochemical Society, vol. 162, no. 1, pp. C47-C54, 2015. 

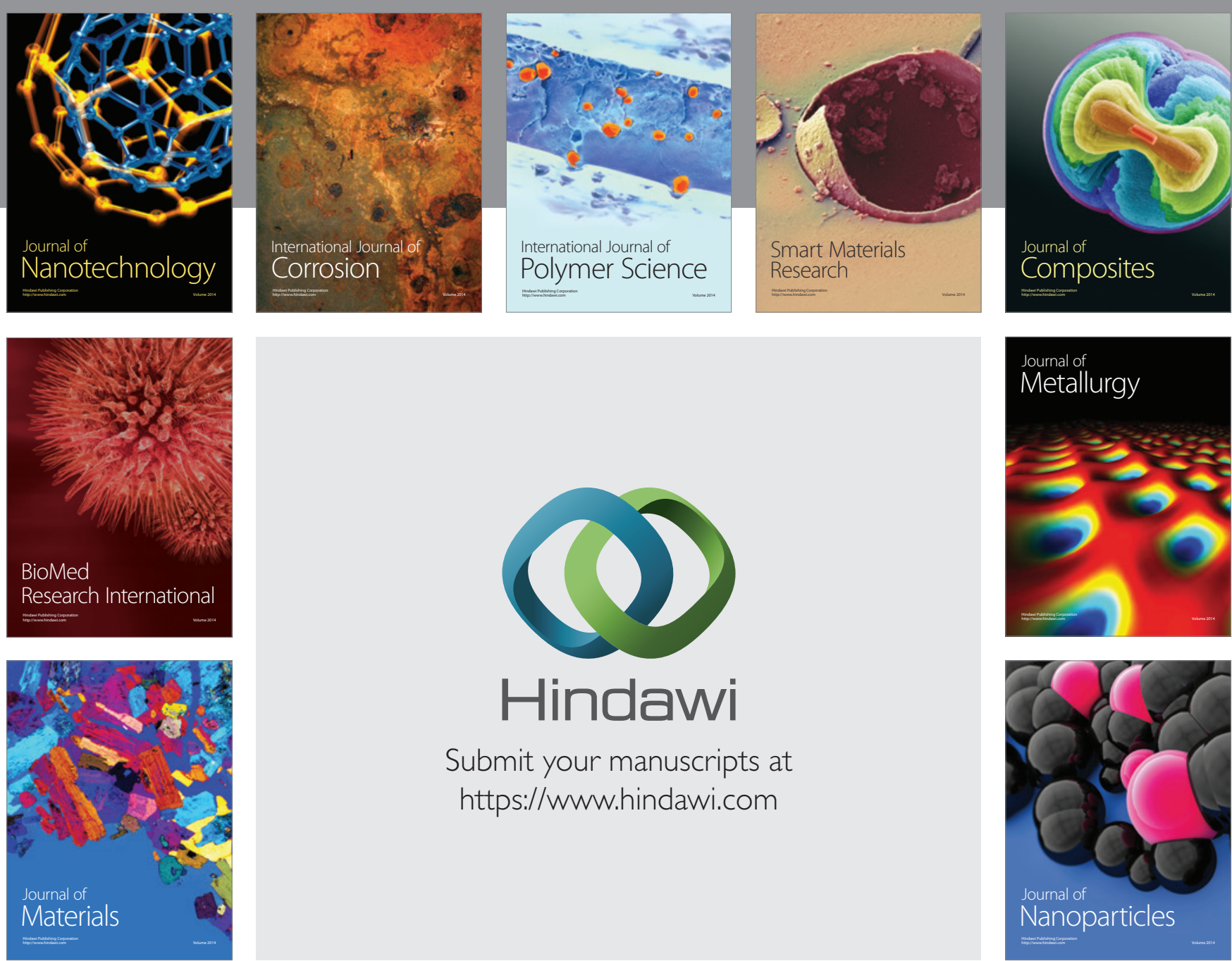

\section{Hindawi}

Submit your manuscripts at

https://www.hindawi.com

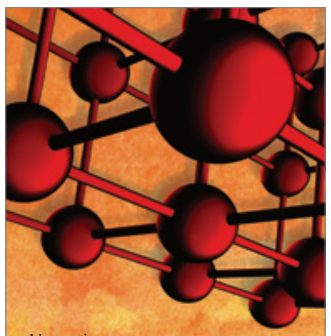

Materials Science and Engineering
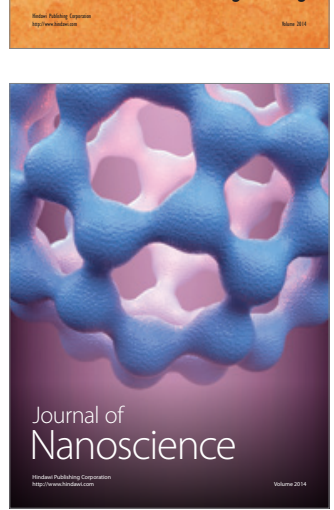
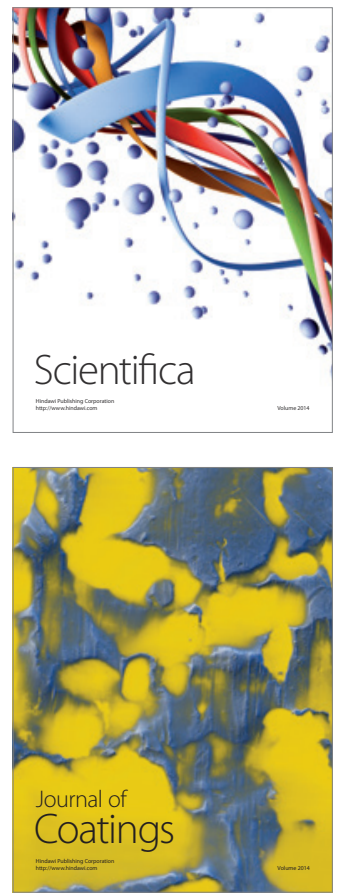
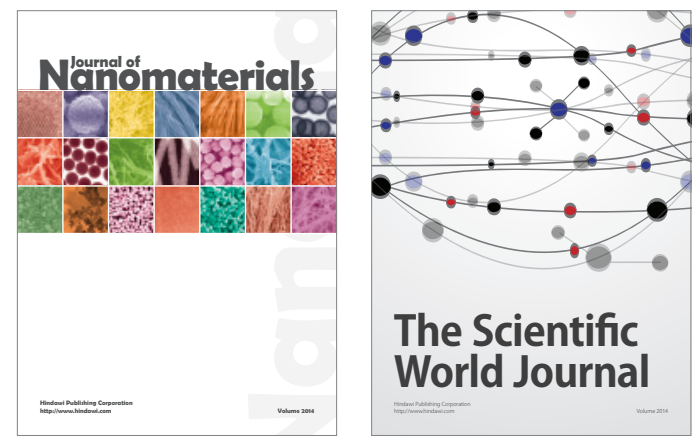

The Scientific World Journal
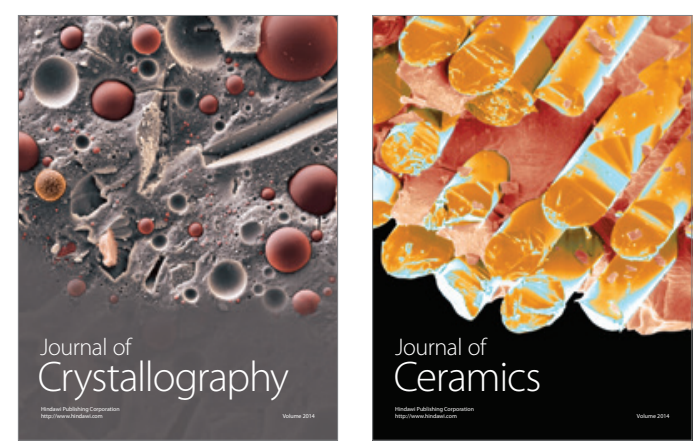
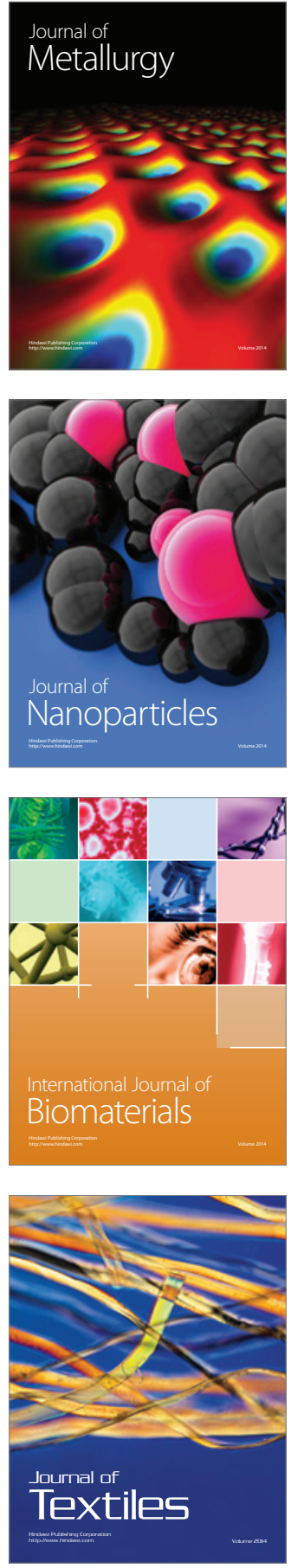